\title{
Testing of Combined DPF+SCR Systems for HD-retrofitting - VERTdePN
}

\section{J. Czerwinski and Y. Zimmerli \\ AFHB}

\section{A. Mayer \\ TTM}

N. Heeb

EMPA

J. Lemaire

AEEDA

\section{G. D'Urbano}

FOEN

\section{R. Bunge \\ UMTEC}

\begin{abstract}
New Diesel exhaust gas aftertreatment systems, with

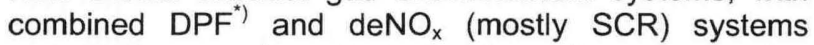
represent a very important step towards zero emission Diesel fleet. These combined systems are already offered today by several suppliers for retrofitting of HD vehicles.
\end{abstract}

Reliable quality standards for those quite complex systems are urgently needed to enable decisions of several authorities.

The present report informs about the international network project VERT *) dePN (de-activation, decontamination, disposal of particles and $\mathrm{NO}_{\mathrm{x}}$ ), which was started in Nov. 2006 with the objective to introduce the SCR-, or combined DPF+SCR-systems in the VERT verification procedure.
Examples of results for some of the investigated systems are given. These investigations included parameters, which are important for the VERT quality testing: besides the regulated gaseous emissions several unregulated components such as $\mathrm{NH}_{3}, \mathrm{NO}_{2}$ and $\mathrm{N}_{2} \mathrm{O}$ were measured. The analysis of nanoparticle emissions was performed with SMPS and NanoMet.

${ }^{*}$ ) Abbreviations see at the end of paper

\footnotetext{
The Engineering Meetings Board has approved this paper for publication. It has successfully completed SAE's peer review process under the supervision of the session organizer. This process requires a minimum of three (3) reviews by industry experts.

All rights reserved. No part of this publication may be reproduced, stored in a retrieval system, or transmitted, in any form or by any means, electronic, mechanical, photocopying, recording, or otherwise, without the prior written permission of SAE. ISSN 0148-7191

Positions and opinions advanced in this paper are those of the author(s) and not necessarily those of SAE. The author is solely responsible for the content of the paper.
SAE Customer Service: Tel: $\quad 877-606-7323$ (inside USA and Canada) Tel: $\quad$ 724-776-4970 (outside USA) Fax: $\quad 724-776-0790$
Email: CustomerService sae.ord

SAE Web Address: nto:/hwm sae oro

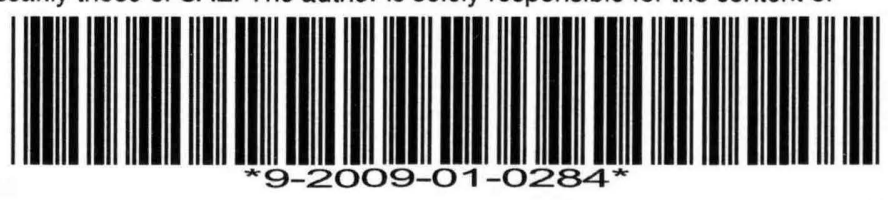

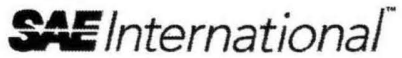


The most important findings from the tested systems are:

- the investigated combined dePN systems $(\mathrm{DPF}+\mathrm{SCR})$ for dynamic engine application efficiently reduce the target emissions with deNO ${ }_{x}$ efficiencies up to $92 \%$ (if operated in the right temperature window) and particle number filtration efficiency up to $100 \%$,

- the ammonia slip can be efficiently eliminated by the slip-cat,

- the average $\mathrm{NO}_{x}$ conversion rate at transient operation (ETC) strongly depends on the exhaust gas temperature profile and the resulting urea dosing control,

- The particle number filtration efficiency, which is verified at stationary engine operation, is perfectly valid also at the transient operation.

The presented exemplary results concern the part of testing procedures on engine dynamometer. They will be confirmed in the further project activities with other systems and with different testing cycles. A special attention will be paid to the operational profiles, which are representative for low emissions zones LEZ.

The entire VERTdePN testing procedure is still under development.

\section{INTRODUCTION}

Laboratories for IC-Engines and Exhaust Emission Control of the University of Applied Sciences Biel, Switzerland (AFHB) participate since 1992 at the Swiss activities about nanoparticle analytics and DPF verification.

The upcoming developments of deNO $\mathrm{N}_{\mathrm{x}}$ (especially SCR) systems and the combinations with DPF's offer a large amount of variants and technical complexity, which represent new challenges not only for the manufacturers, but also for the users and for the responsible authorities.

The Swiss Federal Office of Environment BAFU and the Swiss Federal Roads Office ASTRA decided to support further activities of VERT to develop appropriate testing procedures and to define the quality criteria of dePN systems for retroffiting.

In the VERTdePN project AFHB collaborates closely with several Swiss specialists of chemistry, catalysis, measuring techniques and combisystems (EMPA, PSI, SUVA, ME, UMTEC), as well as European specialist from JRC Ispra, I; TNO \& VROM, NL; AEEDA, B; FAD and TÜV D; AKPF, A.
The application of combined systems (DPF+SCR) as retrofitting raises different technical and commercial problems. In general opinion, this retofitting will be possible mostly through the incentives, or restrictions with respect to low emission zones LEZ, [1] and decisions of several authorities.

The present paper shows the testing procedures of VERTdePN at the current development stage and some examples of results from two very advanced combined retrofitting systems.

\section{AVAILABLE TECHNICAL INFORMATION}

\section{DPF+SCR}

The combination of particle filtration (DPF) and of the most efficient deNO ${ }_{x}$ technology (SCR) is widely considered as the best solution, up to date, to minimize the emissions of Diesel engines. Intense developments are on the way by the OEM's and a lot of research is performed, [2-16].

The removal of $\mathrm{NO}_{\mathrm{x}}$ from lean exhaust gas of Diesel engines (also lean-burn gasoline engines) is a challenge. Selective catalytic reduction (SCR) uses a supplementary substance, a reducing agent, which in presence of catalysts produces useful reactions transforming $\mathrm{NO}_{\mathrm{x}}$ in $\mathrm{N}_{2}$ and $\mathrm{H}_{2} \mathrm{O}$.

The preferred reducing agent for toxicological and safety reasons is a water solution of urea (AdBlue), which due to reaction with water (hydrolysis) and due to thermal decomposition (thermolysis) produces ammonia $\mathrm{NH}_{3}$, which is the actual reducing substance.

A classical SCR deNO ${ }_{x}$ system consists of four catalytic parts:

- precatalyst converting $\mathrm{NO}$ to $\mathrm{NO}_{2}$ (with the aim of 50/50 proportion)

- injection of AdBlue (with the intention of best distribution and evaporation in the exhaust gas flow)

- hydrolysis catalyst (production of $\mathrm{NH}_{3}$ )

- selective reduction catalyst (several deNO $\mathrm{N}_{\mathrm{x}}$ reactions)

- oxidation catalyst (minimizing of $\mathrm{NH}_{3}$ slip).

The main deNO $\mathrm{N}_{x}$-reactions between $\mathrm{NH}_{3}, \mathrm{NO}$ and $\mathrm{NO}_{2}$ are widely mentioned in the literature [2-22]. They have different rates depending on the nature of the catalyst, the exhaust temperature, space velocity and stoichiometry of the reducing agent. This offers a complex situation during transient engine operation. 
Additionally to that there exists an optimal temperature window for each catalyst and cut off temperature for the AdBlue-injection to prevent the deposits on the catalyst.

Several side reactions can occur forming secondary pollutants. An objective is to minimize the tail pipe emissions of: ammonia $\mathrm{NH}_{3}$, nitrous oxide $\mathrm{N}_{2} \mathrm{O}$, isocyanic acid $\mathrm{HNCO}$ and ammonium nitrate $\mathrm{NH}_{4} \mathrm{NO}_{3}$ and other secondary nanoparticles, [17-22].

\section{VERT quality testing}

VERT was in the 1990's a joint project of occupational insurance agencies from Switzerland (SUVA), from Austria (AUVA) and from Germany (TBG) concerning the reduction of emissions of actual machines in tunnel construction, [23, 24, 25].

It was recognized quickly in the VERT project, that the retrofitting with DPF is the most efficient measure to eliminate radically the particle emissions of Diesel engines in underground. To introduce the DPF-systems for retrofitting it was necessary to establish: the quality criteria and quality test procedure, field control and appropriate support to the users.

One of the most important statements of VERT is, that the validation of filtration efficiency of a DPF by means of particle mass PM (legal parameter up to date) is not sufficient and sometimes misleading. In several cases, particularly with the presence of some catalytic substances in the DPF, sulfates can be produced (only the sulfur from lube oil can be sufficient for that), which pass the DPF as vapor and condensate afterwards on the PM-measuring filter. In an extreme case this can cause, that the DPF, which filters perfectly the solid particles (NP, EC e.g. 98\%) seems to double or triple the particle mass (PM).

The filtration efficiency of a DPF can be properly judged only for the solid particles. In this context the nanoparticles are considered in VERT as the most important criterion, [26, 27]. Complementary information is given by a coulometric analysis of elemental carbon (EC) from the collected PM filter residuum.

The nanoparticulates can be measured with different methods and due to the aptitude of penetrating very easily into the living organisms they are regarded as very dangerous for health, $[28,29,30]$.

Since 2001 there are discussions in the international legislative expert groups about possibilities of introducing the NPs as a legally limited parameter, as recommended by the Particulate Measurement Program (PMP) of the UN Working Party on Pollution and Energy (GRPE), [31, 32, 33].
For some systems, which use catalytic coatings, or fuel additives, or combinations of both of them, a VERT secondary emission test (VSET) has to be performed.

For retrofitting with combined systems (DPF+SCR) quality testing and fulfilment of certain criteria are necessary both: for the user and for the authority.

The Swiss VERT Network started the works to include the deNO ${ }_{x}$-systems (SCR, EGR, storage catalysts) in the VERT verification procedures (VERT dePN Programm).

\section{VERTdePN}

\section{Research subjects and objectives}

A general objective of VERTdePN is to include the combined DPF+SCR systems in the test procedures, which were previously developed for DPF retrofitting only.

The VERT quality procedures concern only HD applications.

Since the stationary testing of SCR for onroad application will be not sufficient any more, a simplified dynamic test procedure should be found, which nevertheless would be representative for the legal HD transient testing.

Different variants of catalyst and/or their sequences used for different types of SCR systems, different sequences of DPF and SCR, different possibilities of introduction, homogenization and control of urea and finally different applications offer a large multitude of cases, which will be considered during the tests.

For the VERT DPF quality procedure the research objectives were:

- filtration quality

- durability

- control - \& auxiliary systems

- secondary emissions.

The new objectives for a SCR system in the VERTdePN tests are:

- $\mathrm{NO}_{\mathrm{x}}$ reduction efficiency

- $\mathrm{NO}_{2}$ - and / or $\mathrm{NH}_{3}$ - slip

- emission of $\mathrm{N}_{2} \mathrm{O}$

- operating temperature window

- dynamic operation

- field application \& durability

- auxiliary systems

- further secondary emissions. 
The main structure of VERTdePN tests for combined DPF-SCR is similar, as the preceding VERT activities for DPF, Fig. 1:

- Quality test and basic investigation on dynamic engine dynamometer on a representative HDengine,

- Supervised field test 2000h,

- Analyses of toxic and harmful secondary emissions.

When the DPF of the combined system is already approved by VERT, only simplified tests for the SCR-part will be necessary.

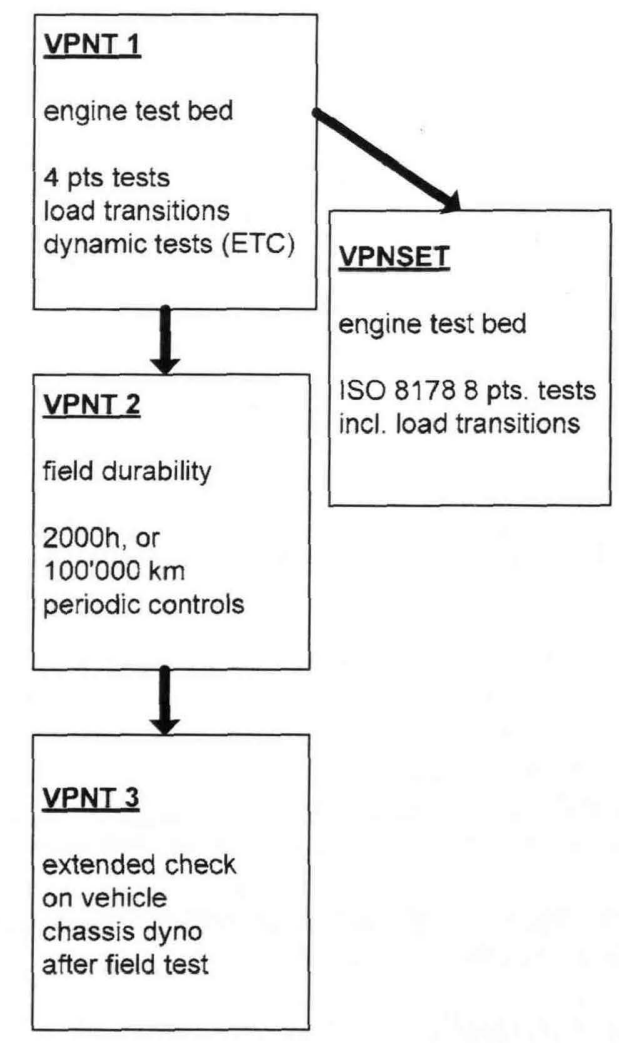

Fig. 1: VERTdePN test procedures for product standards of combined systems (DPF + SCR)

\section{Standards for retrofitted vehicles}

Important questions about: how to use the product standards from VERTdePN to classify the retrofitted vehicles (e.g. for LEZ's) were raised by the representatives of participating authorities.

The steering committee worked further in several meetings on these problems and elaborated some possible procedures of testing and vehicle admission in Switzerland, see the chart in Fig. 2.

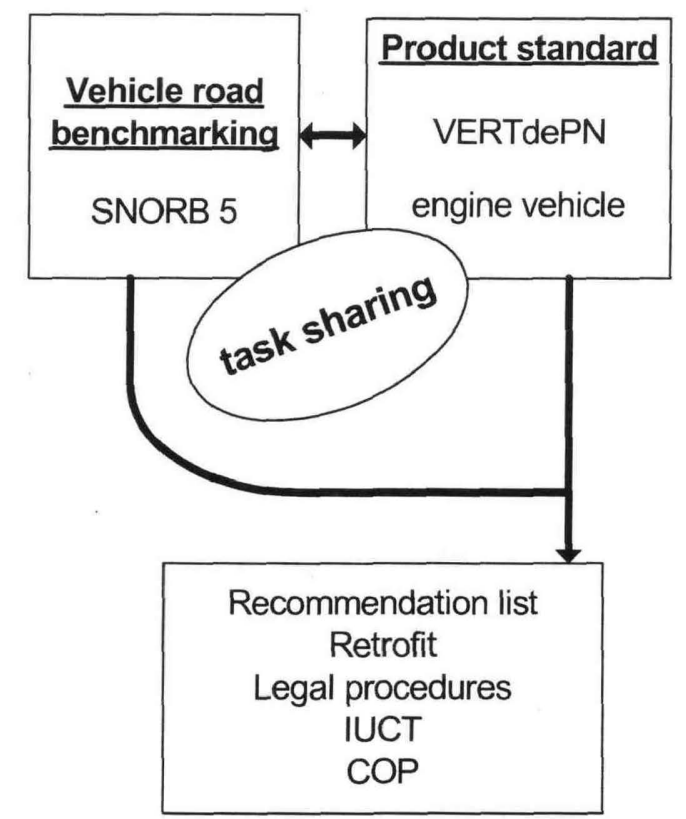

Fig. 2: VERTdePN test procedures for product standards and legal admission of combined systems (DPF + SCR)

A complementary on road vehicle testing SNORB (Swiss $\mathrm{NO}_{x}$ Road Benchmarking) was proposed.

It is important to point out, that the expression "vehicle homologation" was replaced by "vehicle benchmarking", since a strict homologation procedure according to the EU-steps would, due to complexity and costs, eliminate the possibility of retrofitting inuse diesel engines with combined deNOx-DPF systems.

In the present state of discussions the following main points can be remarked:

- retrofitting, as a quicker and more efficient measure to reduce consequently the air pollution, makes much sense for the society,

- if any authority wants to support retrofitting it has to do it among others by means of more flexible requirements and procedures; this flexibility can and should be adapted to the different levels of political decisions, Fig. 3.

- VERT procedures offered the quality standards, guidelines and choice of systems for DPFretrofitting,

- VERTdePN proposes the solutions for DPF+SCR retrofitting,

- important elements of the test procedures are the extensive tests of the product on an engine dynamometer connected with different kind of vehicle testing, 


\section{SNORB 5}

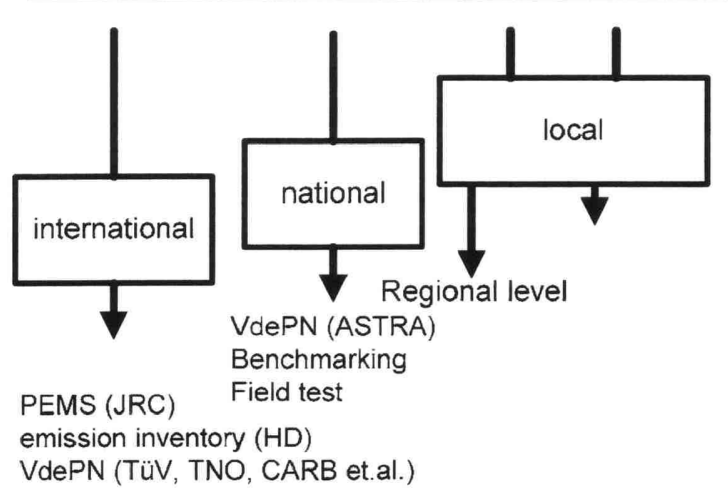

Fig. 3: Swiss $\mathrm{NO}_{x}$ Road Benchmarking EU 5 validation of retrofitting on different political levels

- there are three kinds of on road testing proposed:

- on road real world vehicle benchmarking and comparison with $\mathrm{OE}$ vehicles with similar technology (proposed project SNORB to be started during 2008),

- field test with intermediate and final control on the chassis dynamometer (VPNT2 \& VPNT3),

- simplified acceptance test (vehicle stand still).

Further details of these procedures will be elaborated in the coming VERTdePN activities.

\section{TEST-ENGINE, FUEL AND LUBRICANT}

\section{Test engine}

There are following engine data:

$\begin{array}{ll}\text { Manufacturer: } & \text { Iveco, Torino Italy } \\ \text { Type: } & \text { F1C Euro 3 } \\ \text { Displacement: } & \text { 3.00 Liters } \\ \text { RPM: } & \text { max. 4200 rpm } \\ \text { Rated power: } & \text { 100 kW@3500rpm } \\ \text { Model: } & 4 \text { cylinder in-line } \\ \text { Combustion process: } & \text { direct injection } \\ \text { Injection system: } & \text { Bosch Common Rail / 1600 bar } \\ \text { Supercharging: } & \text { turbocharger with intercooling } \\ \text { Emission control: } & \text { none } \\ \text { Development period: } & \text { until 2000 (Euro 3) }\end{array}$

Fig. 4 shows the engine and the apparatus for nanoparticle analytics SMPS \& NanoMet in the laboratory for IC-engines, University of Applied Sciences, Biel-Bienne.

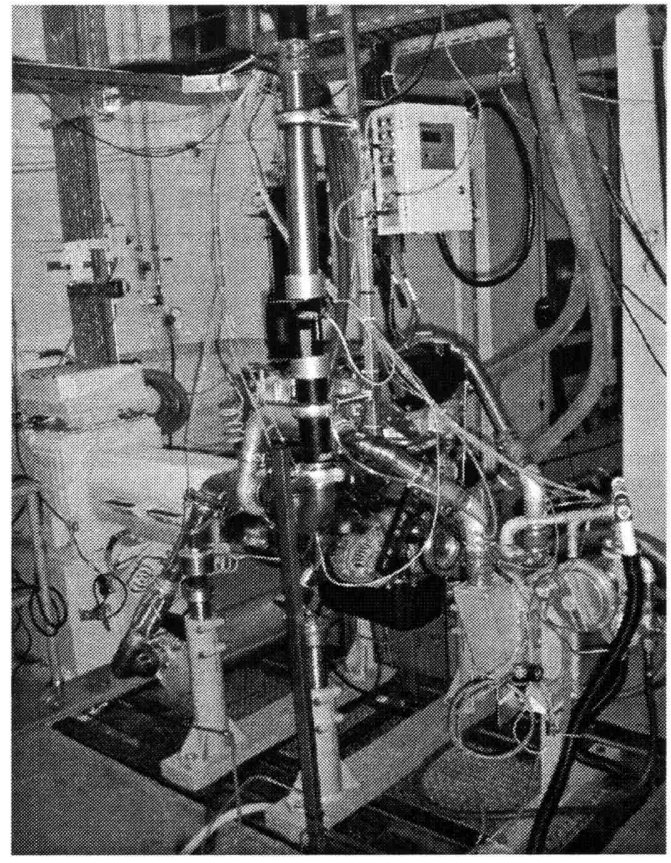

Fig. 4a: IVECO engine $\mathrm{F} 1 \mathrm{C}$ with the dynamic dynamometer.

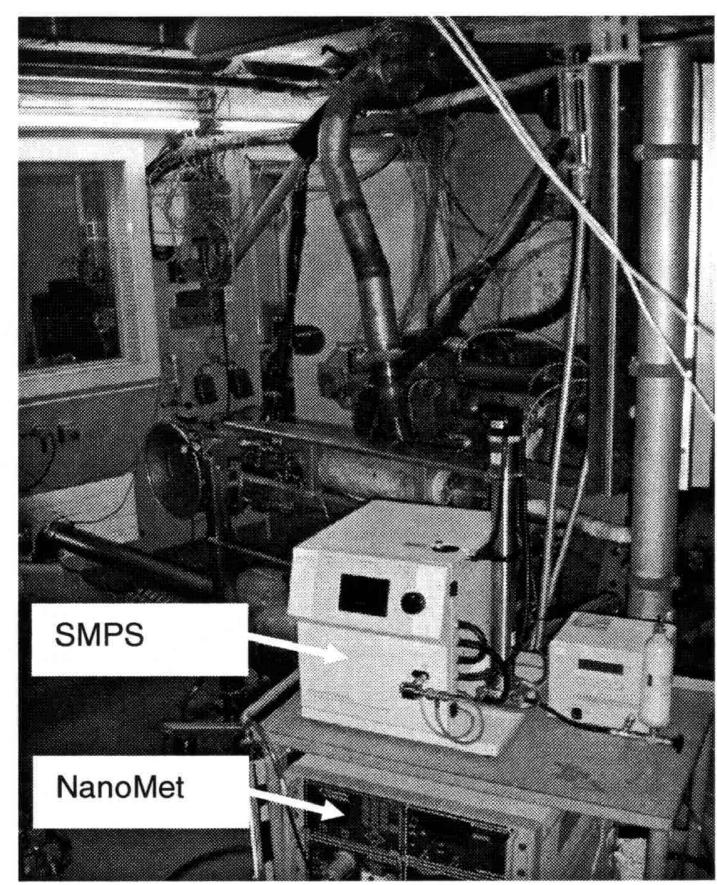

Fig. 4b: Equipment for nanoparticle measurements in the engine room 
Fuel

Following fuel was used for the research:

- Shell Formula Diesel fuel Swiss market summer quality (10 ppm S) according to SN EN 590

Table 1 represents the most important data of the fuel according to the standards.

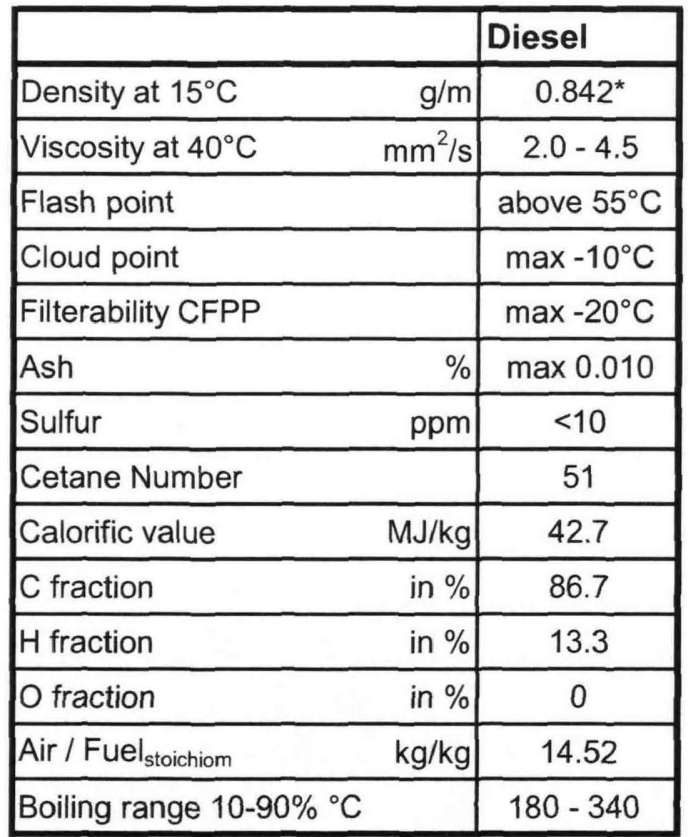

Table 1: Fuel properties as per EUstandards (EN)

\section{Lubricant}

For all tests a lubricating oil Mobil 1 ESP Formula 5W-30 was used. This oil is recommended by the engine manufacturer.

Table 2 shows the available data of this oil, ACEA classes: C3, A3, B3/B4,

API classes: SL / SM; CF

\begin{tabular}{|l|c|l|}
\hline Property & Mobil & \\
\hline Viscosity kin $40^{\circ} \mathrm{C}$ & 72.8 & $\mathrm{~mm}^{2} / \mathrm{s}$ \\
\hline Viscosity kin $100^{\circ} \mathrm{C}$ & 12.1 & $\mathrm{~mm}^{2} / \mathrm{s}$ \\
\hline Viscosity index & 164 & $(--)$ \\
\hline Density $15^{\circ} \mathrm{C}$ & 0.850 & $\mathrm{~kg} / \mathrm{m}^{3}$ \\
\hline Pourpoint & -45 & ${ }^{\circ} \mathrm{C}$ \\
\hline Flamepoint & 254 & ${ }^{\circ} \mathrm{C}$ \\
\hline Total Base Number TBN & 14.2 & $\mathrm{mg} \mathrm{KOH} / \mathrm{g}$ \\
\hline Sulfur ashes & 6000 & $\mathrm{mg} / \mathrm{kg}$ \\
\hline Sulfur & $7^{\prime} 280$ & $\mathrm{mg} / \mathrm{kg}$ \\
\hline Mg & $<10$ & $\mathrm{mg} / \mathrm{kg}$ \\
\hline Zn & $1^{\prime} 570$ & $\mathrm{mg} / \mathrm{kg}$ \\
\hline Ca & $4^{\prime} 760$ & $\mathrm{mg} / \mathrm{kg}$ \\
\hline P & $1^{\prime} 370$ & $\mathrm{mg} / \mathrm{kg}$ \\
\hline
\end{tabular}

Table 2: Data of the applied lubrication oil (EN)

\section{MEASURING SET-UP AND INSTRUMENTATION}

Engine dynamometer and standard test equipment

Fig. 5 represents the special systems installed on the engine, or in its periphery for analysis of the regulated and unregulated emissions.

Laboratory equipment employed:

- Dynamic test bench Kristl \& Seibt with force transducer HBM T10F

- Tornado Software Kristl \& Seibt

- Fuel flow measurement AIC 2022

- Air mass meter ABB Sensiflow P

- Pressure transducers Keller KAA-2/8235, PD$4 / 8236$

- Thermo-couples Type K

\section{Test equipment for exhaust gas emissions}

Measurement is performed according to the exhaust gas emissions regulations for heavy duty vehicles which are also in force in Switzerland (Directive 2005 / 55 / CE \& ISO 8178): 


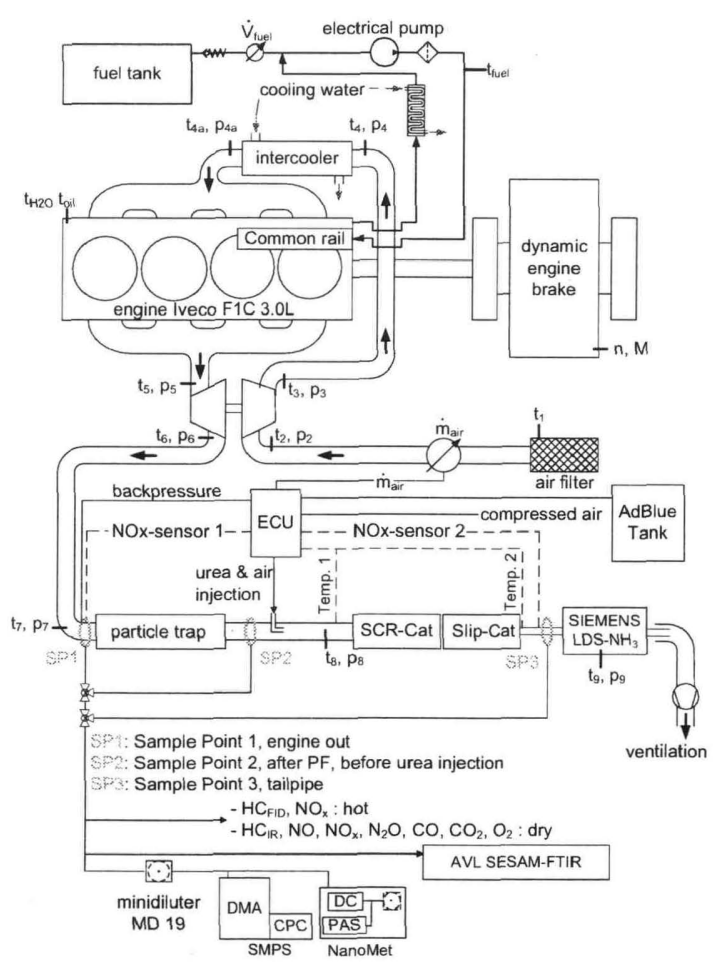

Fig. 5: Engine dynamometer and test equipment

- Volatile components:

- Horiba exhaust gas measurement devices Type: VIA-510 for $\mathrm{CO}_{2}, \mathrm{CO}, \mathrm{HC}_{\mathrm{IR}}, \mathrm{O}_{2}$, Type: CLA-510 for NO, NOx (this standard hot analyser with one reactor is marked in this report as "1 CLD")

- Amluk exhaust gas measurement device Type: FID 2010 for $\mathrm{HC}_{\mathrm{FID}}$,

- $\quad \mathrm{NH} 3$ and N2O:

With SCR several unregulated and secondary pollutants can be produced. The slip of gaseous components such as ammonia $\mathrm{NH}_{3}$ and nitrous oxide $\mathrm{N}_{2} \mathrm{O}$ was measured by means of:

- Siemens LDS 6 Laser Analyzer 7MB 6021, $\mathrm{NH}_{3}$

- Siemens ULTRAMAT 6E 7MB2121, $\mathrm{N}_{2} \mathrm{O}$

- Eco physics CLD $822 \mathrm{CM}$ hr with hot line for NO, $\mathrm{NO}_{2}, \mathrm{NO}_{3}, \mathrm{NH}_{3}$ (this analyzer with two reactors is marked in this report as "2 CLD")

- FTIR (Fourier Transform Infrared) Spectrometer (AVL SESAM) with the possibility of simultaneous, time-resolved measurement of approx. 30 emission components - among those validated are: $\mathrm{NO}, \mathrm{NO}_{2}$, $\mathrm{NO}_{x}, \mathrm{NH}_{3}, \mathrm{~N}_{2} \mathrm{O}$.

\section{Particle size analysis}

To estimate the filtration efficiency of the DPF, as well as to detect the possible production of secondary nanoparticles, the particle size and number distributions were analysed with following apparatus, Fig. 4b:
- SMPS - Scanning Mobility Particle Sizer, TSI (DMA TSI 3071, CPC TSI 3025 A)

- NanoMet - System consisting of:

- PAS - Photoelectric Aerosol Sensor (EcoChem PAS 2000) indicates the carbonaceous total surface of the aerosol

- DC - Diffusion Charging Sensor (Matter Eng. LQ1-DC) indicates the totale surface of the aerosol independently of the chemical properties

- MD19 tunable minidiluter (Matter Eng. MD192E)

- Thermoconditioner (TC) (i.e. MD19 + postdilution sample heating until $300^{\circ} \mathrm{C}$ ).

The nanoparticle results represented in this paper are obtained with sampling at tail pipe with MD19 and with thermoconditioner $\left(300^{\circ} \mathrm{C}\right)$.

The nanoparticulate measurements were performed at constant engine speed (warm) with SMPS and NanoMet. During the dynamic engine operation NanoMet and CPC were used.

\section{TEST PROCEDURES}

According to the different objectives of the project several test procedures were used.

After analyzing the backpressure of the system in the entire engine operation map it was decided to limit the operation range in the way, that the backpressure value of 200 mbar would not be exceeded at stationary engine operation.

Fig. 6 shows the limited engine map, the 8-point ISO 8178 cycle in this limited map and the 4-point test, used for VPNT1.

engine map : IVECO F1C CR, DI, TCl, 3 dm3

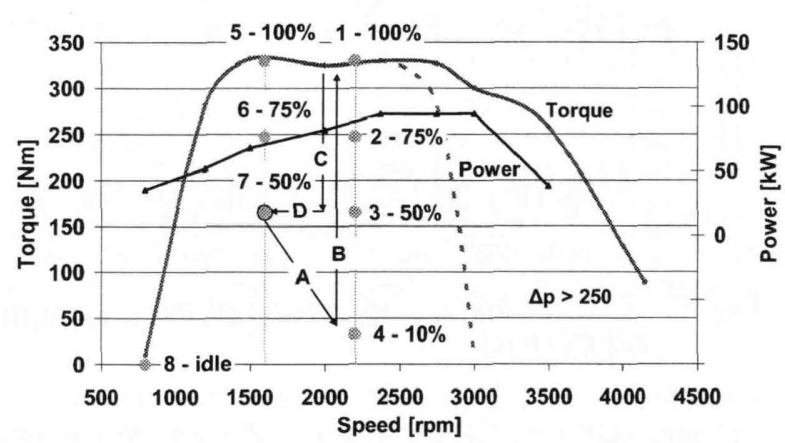

Fig. 6: 8pts. test (ISO 8178) in the limited engine map and setting of the VPNT1 4 pts. test

The 8-points cycle was also used for the secondary emission test VPNSET developed at EMPA. These tests were performed in the present work with three different feed factors $\alpha$ *).

\section{${ }^{\star}$ ) Abbreviations see at the end of paper}


For the tests concerning: filtration efficiency, deNO $\mathrm{N}_{\mathrm{x}}$-rate, unregulated parameters, some basic studies on the investigated systems were performed in the 4-points test according to VPNT1 (AFHB).

These operating points are (in the following sequence):

- operating point 7: $50 \%$ load, intermediate speed 1, $1600 \mathrm{rpm} / 50 \%$,

- operating point 4: 10\% load, intermediate speed 2, $2200 \mathrm{rpm} / 10 \%$,

- $\quad$ operating point 1: $100 \%$ load, intermediate speed 2, $2200 \mathrm{rpm} / 100 \%$,

- $\quad$ operating point 3: $50 \%$ load, intermediate speed 2, $2200 \mathrm{rpm} / 50 \%$,

- operating point 7: repetition.

The four operating points were chosen in such way, that the switching "off" and "on" of the urea-dosing is included in the tests (pt. $7 \rightarrow$ pt. 4 and pt. $4 \rightarrow$ pt. 1).

For a more detailed investigation of the tested system different sampling positions (SP) were used (see Fig. 5):

SP 0 sampling engine out w/o aftertreatment system

SP 1 sampling engine out with aftertreatment system

SP 2 sampling engine after DPF (before urea dosing) with aftertreatment system

SP 3 sampling engine at tailpipe with aftertreatment system.

This designation of sampling positions is used in the presented figures and in the discussion of results.

The dynamic testing was started with the European Transient Cycle ETC, which was first defined on the basis of the limited engine operation map, Fig. 7.

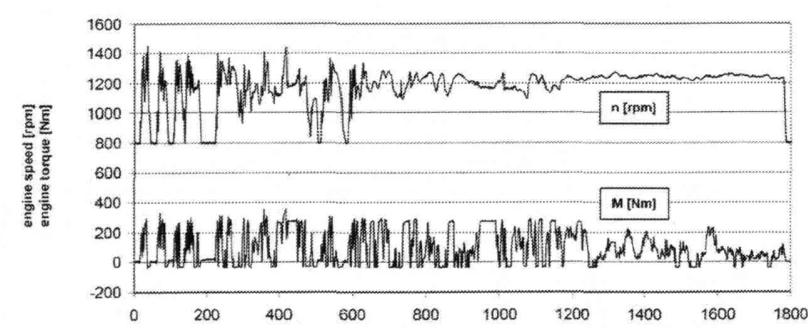

Fig. 7: ETC for the limited version of the engine map, IVECO F1C.
The tests were driven after a warm-up phase, when the engine coolant temperature and lube oil temperature reached their stationary values (stationary points tests).

Before the start of each dynamic cycle the same procedure of conditioning was used to stabilize the thermal conditions of the exhaust gas aftertreatment system. This conditioning was: $5 \mathrm{~min}$ at point 1 and 0.5 min of idling.

\section{RESULTS}

The results were obtained from combined systems consisting of a coated DPF upstream the urea dosing and a SCR catalyst downstream (as in Fig. 5).

Between DPF and SCR there was a mixing tube of $1.0 \mathrm{~m}$, without mixer.

Sometimes an ammonia slip catalyst was used as a modulus at the end of the system. This (DPF+SCR) system is designed for transient application. It has an electronic control unit, which uses the signals of: air flow, $\mathrm{NO}_{x}$ before/after system and temperatures before/after SCR modulus.

\section{Stationary engine operation}

Fig. 8 shows the time-plots of $\mathrm{NO}_{x}$ and $\mathrm{NH}_{3}$ in the 8points test with different urea feed factors $\boldsymbol{\alpha}$. Increasing the feed factor up to $\alpha=1.2$ enables a deNO $_{x}$ efficiency up to $98 \%$, but also increases the ammonia slip up to $125 \mathrm{ppm}$. Table 3 illustrates this at one operating point (2200 rpm / 100\%). At low load operation (OP 4 \& OP 8 ) there is no urea feeding and consequently no $\mathrm{NO}_{x}$-reduction.

\begin{tabular}{|l|c|c|c|c|}
\cline { 3 - 5 } \multicolumn{1}{c|}{} & \multirow{2}{*}{ w/o } & \multicolumn{3}{|c|}{ with DPF + SCR } \\
\cline { 4 - 6 } \multicolumn{1}{c|}{$2200 \mathrm{rpm} / 100 \%$} & DPF + SCR & $\alpha=0.8$ & $\alpha=1.0$ & $\alpha=1.2$ \\
\hline $\mathrm{NO}_{\mathbf{X}} 1 \mathrm{CLD}[\mathrm{ppm}]$ & 782.0 & 159.0 & 42.0 & 14.0 \\
\hline $\mathrm{RE}_{\mathrm{NOx}}[\%]$ & - & 80.0 & 95.0 & 98.0 \\
\hline $\mathrm{NH}_{3}$ LDS [ppm] & - & 6.0 & 31.0 & 125.0 \\
\hline
\end{tabular}

Table 3: $\quad \mathrm{NO}_{\mathrm{x}}$ reduction efficiency $\mathrm{RE} \& \mathrm{NH}_{3}$ depending on feed factor $\alpha$, (pt. 1 of the 8 pts. test). 

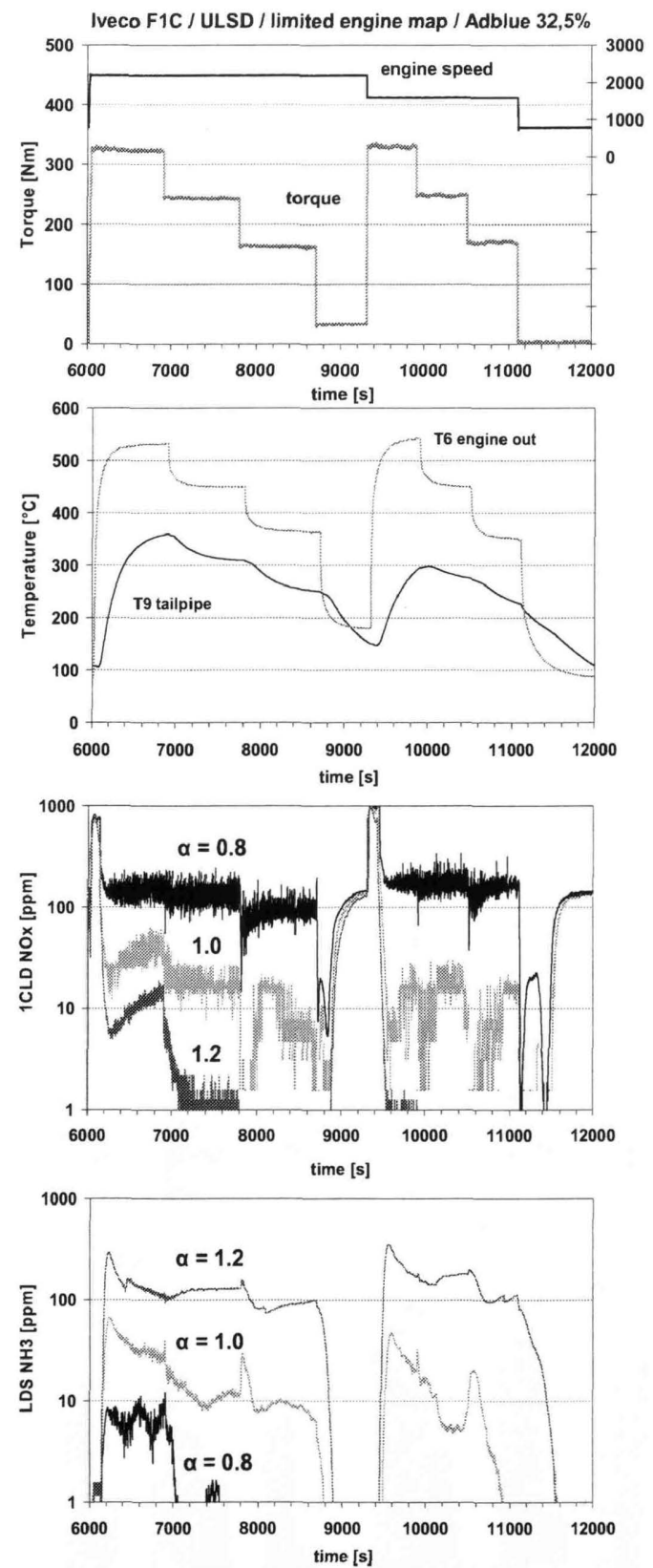

Fig. 8: Comparison of results at 8 points-test with different feed factors $\alpha$

Fig. 9 represents emissions at different sampling positions SP in the 4-points test with $\alpha=0.9$. There are some differences between $\mathrm{CO}$ and $\mathrm{HCs}$ at SPO (without aftertreatment system) and SP1 (before aftertreatment system) caused by a slightly higher backpressure with the installed system.

Due to the use of a catalytic DPF there is an efficient oxidation of $\mathrm{CO}$ and $\mathrm{HCs}$ between SP1 and SP3, except for the low load operation OP4.
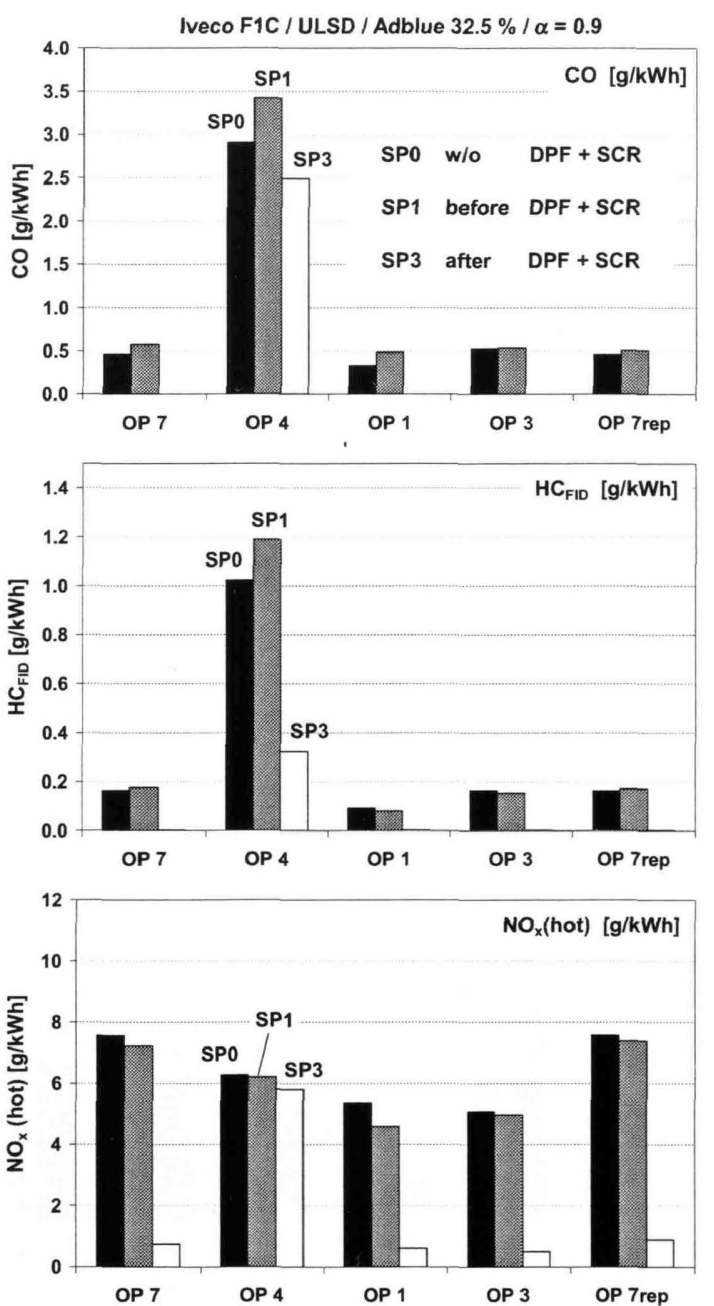

Fig. 9: 4 points test: emission values at different SP's

The verification of conversion rates for $\mathrm{CO}, \mathrm{HC}$ and $\mathrm{NO}_{x}$ as shown in Fig. 10, does not show any significant differences, when refering to engine-out emissions with or without aftertreatment system. The maximum stationary ammonia slip at OP1 is $15 \mathrm{ppm}$.

Fig. 11 shows the results obtained with FTIR at different sampling positions. Comparing engine-out emissions with those of SP2 (after DPF, before urea dosing) and SP3 (after system).

As expected there is an efficient reduction of nitrogen oxide emissions $\mathrm{NO}_{x}$, including $\mathrm{NO}$ and $\mathrm{NO}_{2}$ over the SCR catalysts. Exception is at the low load OP4 with no admission of reducing agent.

The production of $\mathrm{NO}_{2}$ in the catalytic DPF is demonstrated by the emission differences between SPO and SP2 (Fig. 11). At OP4 the exhaust gas temperature is to low and consequently no $\mathrm{NO}_{2}$ is produced. 

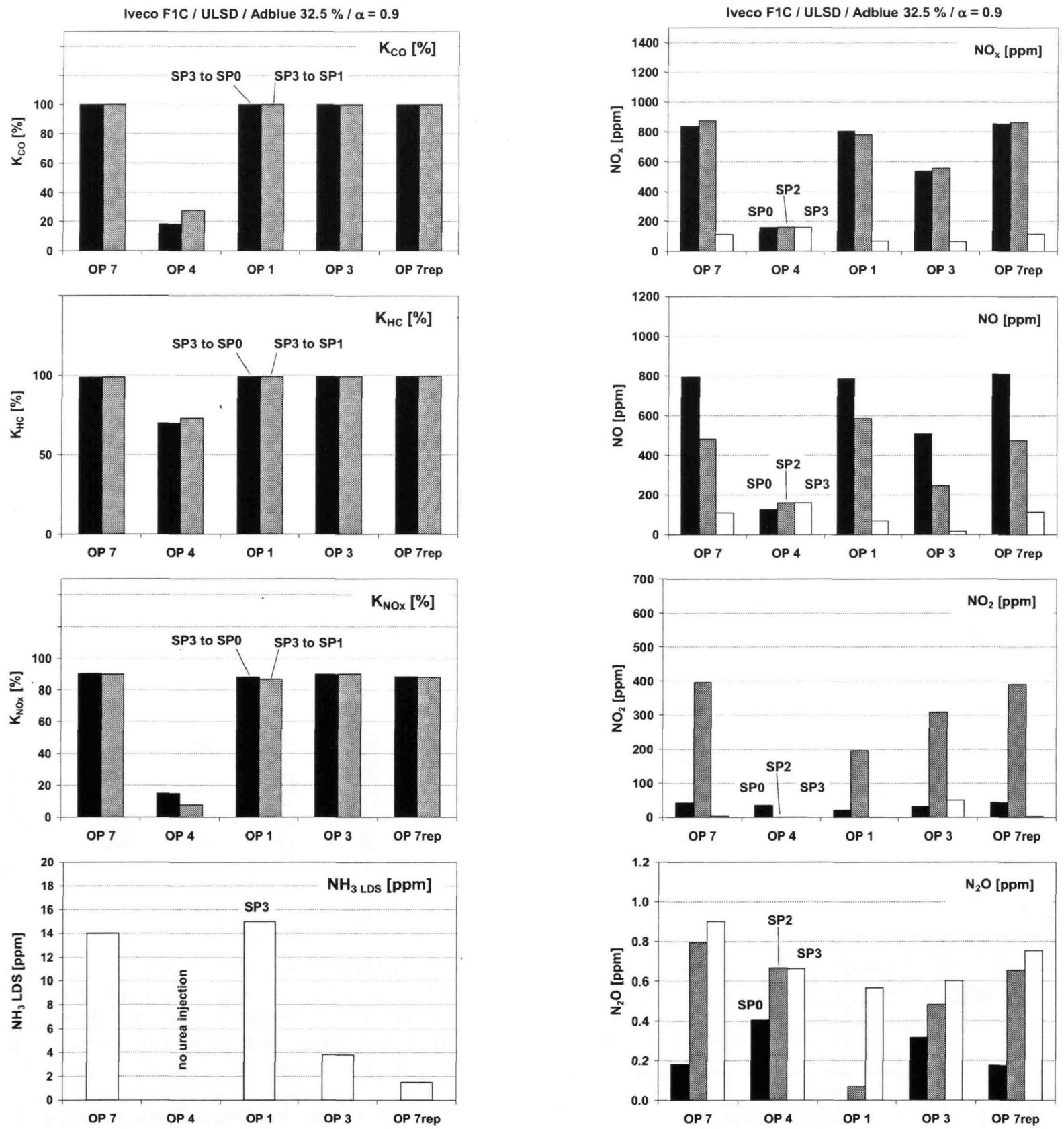

Fig. 10: 4 points test : conversion rates with different SP's \& $\mathrm{NH}_{3}$ tail pipe

Fig. 11a: FTIR results in 4pts. test at different SP's 

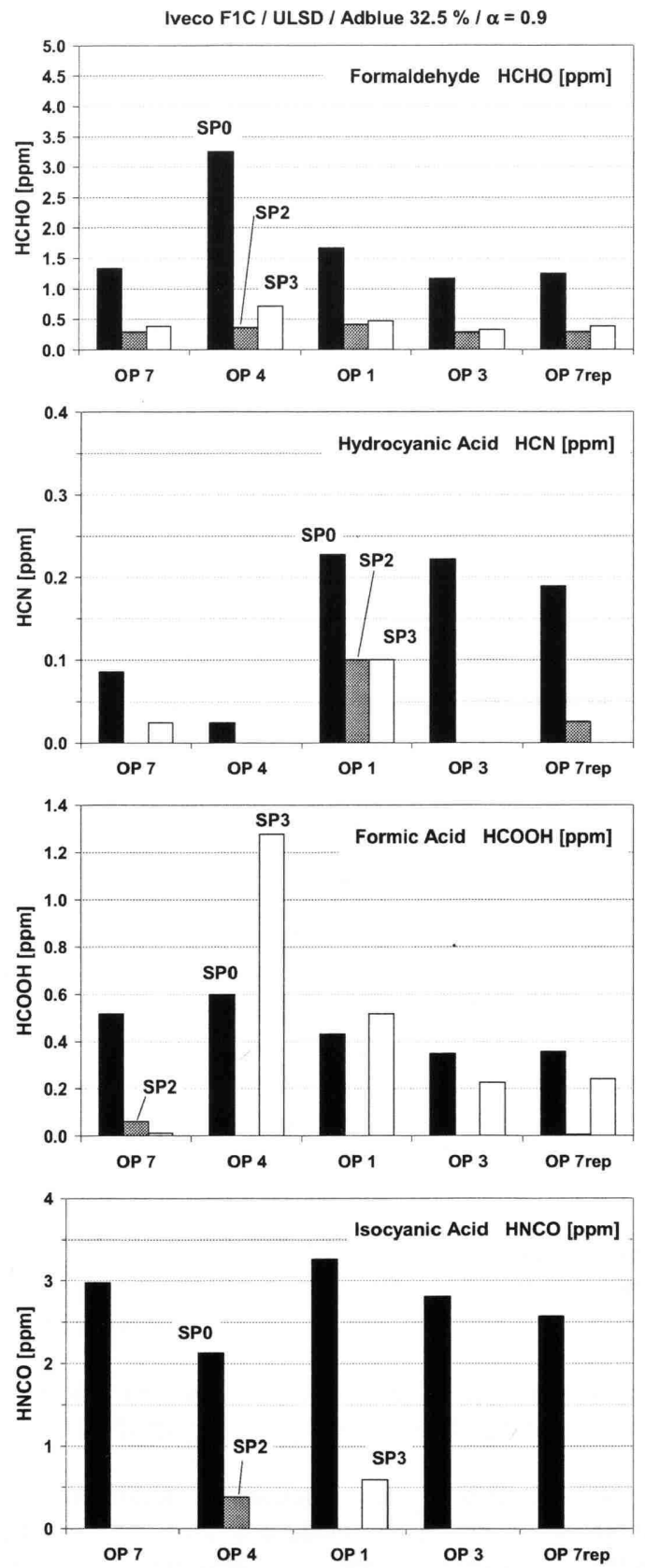

Fig. 11b: FTIR results in 4pts. test at different SP's
$\mathrm{N}_{2} \mathrm{O}$ has the tendency to be partialy increased in the DPF and in the SCR, nevertheless, the released quantities are small (<1ppm).

Measurements of nanoparticles NP in the 4-points test at different sampling positions are represented in Fig.12. Particularly interesting is the look on the SP2 (after DPF, before urea dosing) and SP3 (after the combined dePN system). There is some production of secondary nanoparticles due to the presence of urea and of other reaction products of deNO ${ }_{x}$ chemistry. This is indicated by increased CPC- and DC-values between SP2 and SP3.

The PAS (photoelectric aerosol sensor) is sensitive to the surface of particulates and to the chemical properties of the surface. It indicates solid carbonaceous particles.

The PAS-signals decrease between SP2 and SP3 (Fig. 12), indicating that some of the PAS-active particle surface must be chemicaly changed in the deNOx system.

The DC (diffusion charging sensor) measures the total particle surface independent of the chemical properties of the particles. It indicates both solid particles and condensates and therefore it correlates well with the total nanoparticle counts (CPC). As known from the literature, [17-22], secondary pollutants such as cyanuric acid, ammonium nitrate and others can form during the deNO $\mathrm{N}_{x}$ process. In addition, unreacted urea can also be released. The chemical composition of these secondary aerosols will be studied in further phases of the project. The increase of NP number concentration (CPC) or of the total surface of the aerosol (DC) over the SCRsystem (SP2-SP3) is small compared with the reduction of NP in the DPF (SP0-SP2). Therefore, the secondary formation of nanoparticles does not impact the overall filtration efficiency of the system (notice the logarithmic scale in Fig. 12). Exception is the operating point OP1 with the highest space velocity and an intense secondary formation of nanoparticles. 

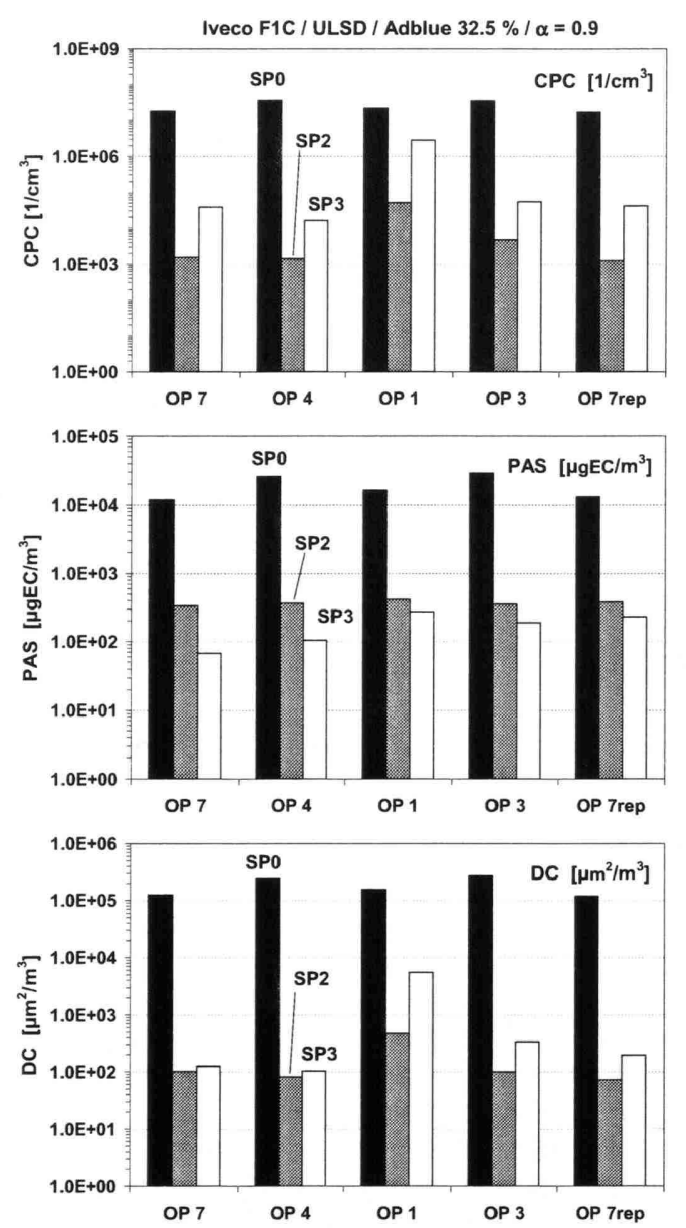

Fig. 12: Secondary nanoparticles at $4 \mathrm{pts}$, test (w/o slip cat.) indicated with total NP counts (CPC) and surface measuring sensors PAS \& DC
A shortened summary of reduction efficiencies RE in the 4-points test without slip cat. is represented in Table 4. $\mathrm{NO}_{x}$ and $\mathrm{NO}_{2}$ - values of CLD and FTIR, as well as all NP-values (CPC, PAS, DC) are given.

At operating points 7, 1 and 3 the SCR system is working in the optimal temperature window and deNO ${ }_{x}$-efficiencies are in the range of $86-91 \%$.

Concerning the $\mathrm{NO}_{2}$ reduction rates there are some open questions: why is the $\mathrm{NO}_{2}$ efficiency so high at OP4 with no urea dosing and why is it so low at OP3, when the urea injection and temperature range are optimal? These questions can be at least partly explained by the dynamic response of the aftertreatment system in the preceeding load transitions.

There are on the one side the thermal memory effects of the different components (DPF, SCR) in the range of $10 \mathrm{~min}$ and on the other side the chemical memory due to store / release effects and secondary reactions.

The presented nanoparticle filtration efficiencies (Table 4) are excellent and confirm the required high quality of the DPF part of the system (except of OP1 with highest space velocity and intese secondary NP formation). 


\begin{tabular}{|c|c|c|c|c|c|c|c|c|c|c|c|c|}
\hline \multirow{3}{*}{$R E_{X}=\frac{X_{w / 0}-X_{w}}{X_{w / 0}} \cdot 100$} & \multicolumn{4}{|c|}{ 4-Pt. SP3 w/o slip catalyst } & \multicolumn{4}{|c|}{ 4-Pt. SP0 Reference } & & & & \\
\hline & \multicolumn{4}{|c|}{ with DPF + SCR } & \multicolumn{4}{|c|}{ without DPF + SCR } & \multicolumn{4}{|c|}{ RE [\%] } \\
\hline & 7 & 4 & 1 & 3 & 7 & 4 & 1 & 3 & 7 & 4 & 1 & 3 \\
\hline Temp. T $7 \quad\left[{ }^{\circ} \mathrm{C}\right]$ & 339 & 177 & 528 & 367 & 337 & 175 & 490 & 350 & & & & \\
\hline $\mathrm{NO}_{\mathrm{x}}$ 1CLD [ppm] & 100 & 143 & 85 & 52 & 760 & 140 & 740 & 490 & 87 & -2 & 89 & 89 \\
\hline $\mathrm{NO}_{\mathbf{x}}$ FTIR [ppm] & 113.97 & 160.22 & 69.86 & 65.42 & 838 & 160 & 808 & 539 & 86 & 0 & 91 & 88 \\
\hline $\mathrm{NO}_{2}$ 1CLD [ppm] & 3 & 1 & 0 & 32 & 40 & 30 & 30 & 30 & 93 & 97 & 100 & -7 \\
\hline $\mathrm{NO}_{2}$ FTIR $[\mathrm{ppm}]$ & 4 & 0.56 & 0.91 & 49 & 42 & 35 & 21 & 33 & 91 & 98 & 96 & -51 \\
\hline$\left[1 / \mathrm{cm}^{3}\right]$ & $3.9 E+04$ & $1.6 \mathrm{E}+04$ & $2.9 E+06$ & $5.6 \mathrm{E}+04$ & $1.9 \mathrm{E}+07$ & 3.7E+07 & $2.2 E+07$ & $3.6 \mathrm{E}+07$ & 100 & 100 & 87 & 100 \\
\hline PAS $\left[\mu \mathrm{gEC} / \mathrm{m}^{3}\right]$ & 67.6 & 104.9 & 274.3 & 190.2 & $1.2 E+04$ & $2.6 \mathrm{E}+04$ & 1.6E+04 & $2.9 \mathrm{E}+04$ & 99 & 100 & 98 & 99 \\
\hline$\left[\mu \mathrm{m}^{2} / \mathrm{cm}^{3}\right]$ & 125.4 & 103.2 & 5542.1 & 337.5 & $1.3 E+05$ & $2.4 E+05$ & $1.6 \mathrm{E}+05$ & $2.7 E+05$ & 100 & 100 & 96 & 100 \\
\hline
\end{tabular}

Table 4: Integral average values and reduction efficiencies of $\mathrm{NO}_{\mathrm{x}}, \mathrm{NO}_{2}$ and $\mathrm{NP}$ in the 4-points test.

\section{Load transitions}

The emissions over the time were monitored for transitions $A, B, C$ and $D$ of the 4-points test (Fig. 6).

Fig. 13 shows as an example the transition $B$ with a load increase from $10 \%$ (OP4) to $100 \%$ (OP1) at 2200 rpm and with urea switching on.

$\mathrm{NO}_{2}$ levels measured before the combined dePN system (SP1) decline at $100 \%$ load, as expected, because of thermal $\mathrm{NO}_{2}$ decomposition at temperatures up to $490{ }^{\circ} \mathrm{C}$ (Table 4).

Measured after the system (SP3) quite long response times of $\mathrm{NO}_{x}$-reduction, in the range of $90 \mathrm{sec}$, are noticed. In this time, exhaust temperatures increase and the urea dosing starts.

According to the conditions of flow, space velocity, temperature and urea stoichiometry $(\boldsymbol{\alpha})$ different SCR reactions proceed.

An increase of nanoparticles concentrations is clearly indicated by both, the CPC- and the DC-signals.

Load transitions between two stationary engine conditions are very indicative to study in detail the instationary changes in the combined system. Nevertheless for some specific purposes longer operation times at the final stationary state are recommended as well. By extreme load changes (from $0 \%$ to $100 \%$ ) the time necessary for thermal and chemical stabilization of the system can be in the range of up to $20 \mathrm{~min}$.

\section{Dynamic engine operation}

These tests were performed in the ETC with limited engine map (LEM).

Following results will be shown:

- $\quad$ ETC1 \& ETC2 with DPF+SCR+slip cat

- ETC3 with DPF+SCR without slip cat

- ETC4 reference (w/o DPF+SCR).

Before starting each test the thermal condition of the exhaust system was stabilized by repetitive conditioning (see Test Procedures).

Fig. 14 compares emissions during two ETC's with and without slip catalyst. During both tests, exhaust temperatures at the tailpipe decreased below $200{ }^{\circ} \mathrm{C}$ and in the second part of the test $\mathrm{NO}_{\mathrm{x}}$ emissions increased because of stopped urea dosage.

The ammonia slip catalyst reduced $\mathrm{NH}_{3}$ emissions, most efficiently in the first phase of the test (until approx. $200 \mathrm{~s}$ ).

In the first phase of the test (until approx. $500 \mathrm{~s}$ ) there are also higher emission peaks of NP-emissions CPC \& DC, which are an effect of the highly instationary chemistry, production of secondary nanoparticles and store/release phenomena. In the second part of the measuring cycle with less fluctuating engine speed there are also less fluctuations in the CPC- and DCplots. 

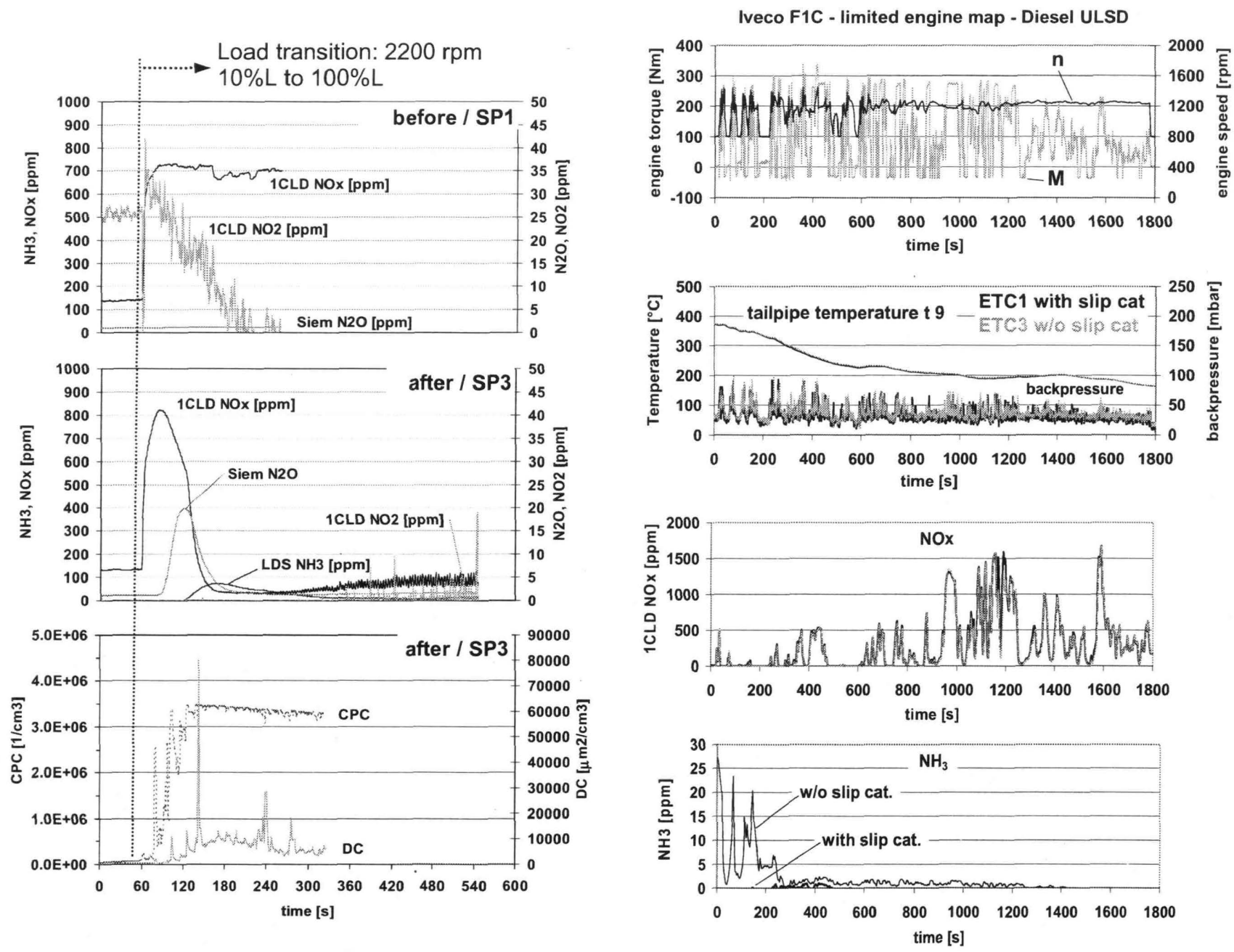

Load transition: $2200 \mathrm{rpm}$
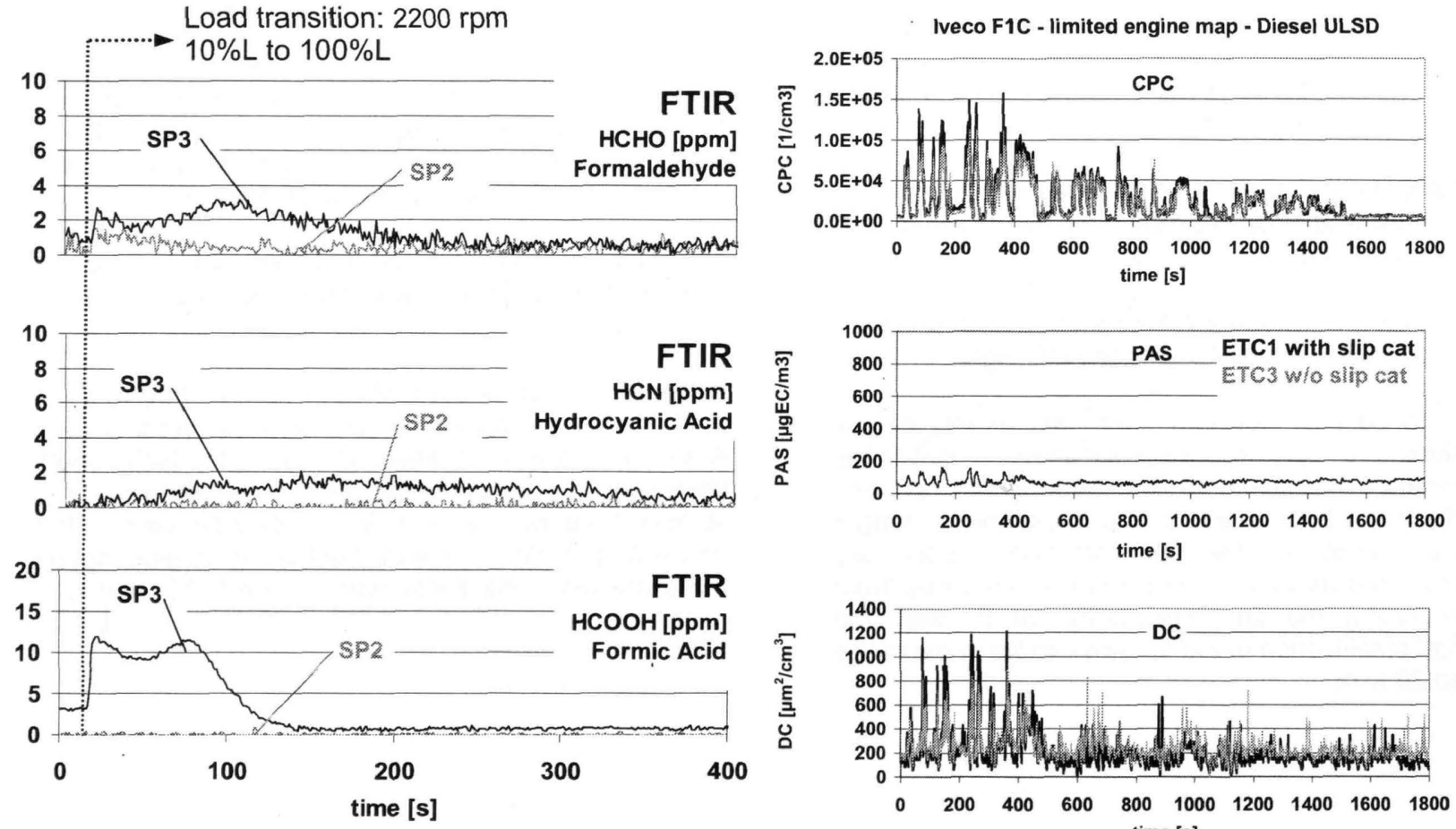

Fig. 13: Load transition B: from $2200 \mathrm{rpm} /$ $10 \% \mathrm{~L}$ to $2200 \mathrm{rpm} / 100 \% \mathrm{~L}$ with measurements before and after DPF + SCR

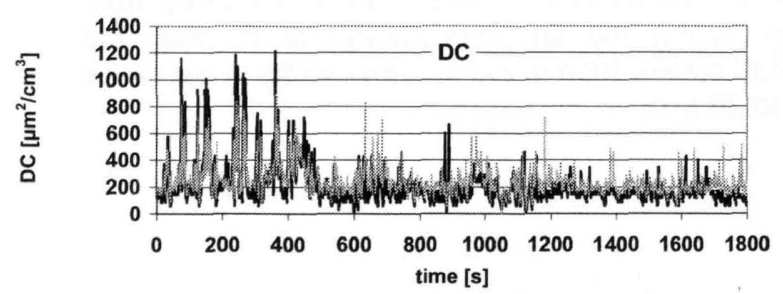

Fig. 14: Comparison of 2 ETC's (ETC1-ETC3), with \& w/o slip catalyst $\alpha=0.9$ 
Fig. 15 depicts the decreasing $\mathrm{NO}_{x}$ conversion efficiency caused by the cooling of the exhaust system during the test and the respective shut-off of urea dosage. It can be concluded, that with better insulation of the exhaust system, or placing the dePN system closer to the engine, or extending the engine operation range, the deNO $\mathrm{N}_{\mathrm{x}}$ reduction rates can be influenced. Some of these measures will be tested in further works.
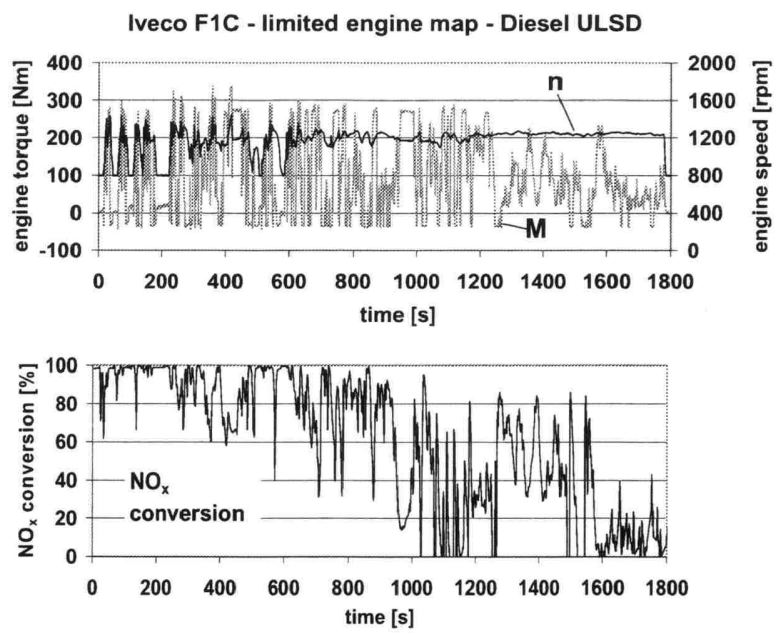

Fig. 15: Comparison of 2 ETC's (ETC3-ETC4), reference \& w/o slip catalyst $\alpha=0.9$, (LEM)

The results of target emission were integrated for different test periods:

- initial period 0-400 s

- $\quad$ final period 1400-1800 s

- overall test 0-1800 s.

The obtained average emission concentration and the reduction efficiencies are summarized in Table 5.

The $\mathrm{NO}_{x^{-}}$and $\mathrm{NO}_{2}$-conversion rates decrease during the test, as previously discussed. The $\mathrm{NO}_{\mathrm{x}}$ concentrations obtained from CLD and FTIR correspond very well. $\mathrm{NO}_{2}$ levels are rather low, therefore discrepancies are larger.
Again, very high filtration efficiencies of $99-100 \%$ were noticed despite of some secondary NPformation in all periods of the ETC.
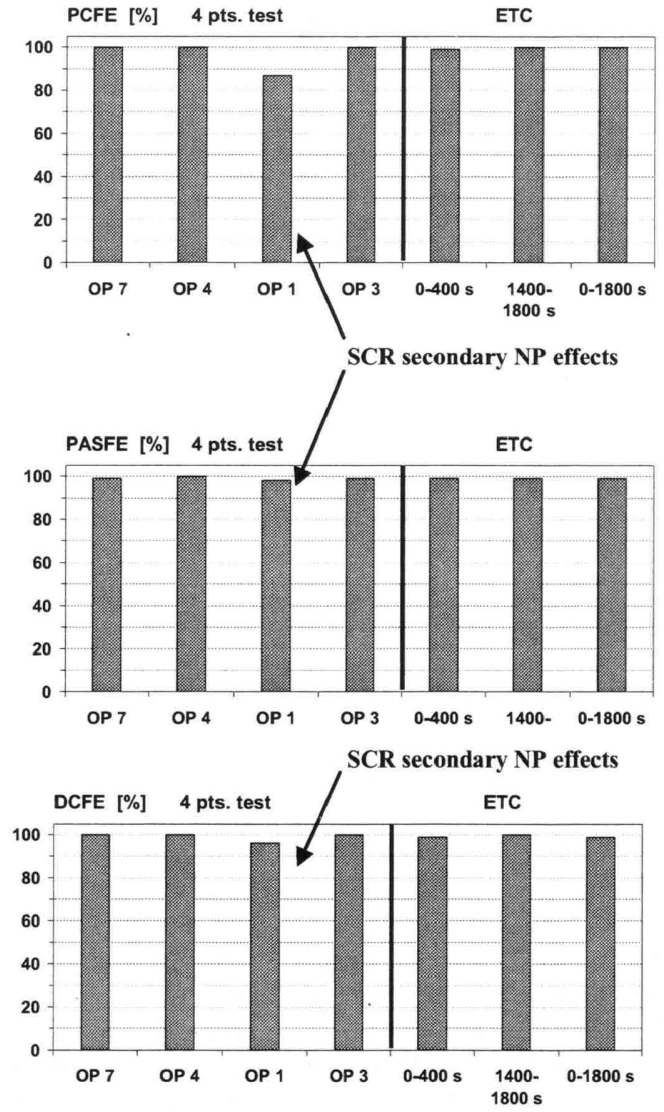

Fig. 16: Filtration efficiencies of the combisystem after SCR - catalyst in stationary and dynamic engine operation

Fig. 16 compares filtration efficiencies of the combined dePN system (DPF+SCR) in stationary and in dynamic engine operation. 


\begin{tabular}{|c|c|c|c|c|c|c|c|c|c|}
\hline \multirow{3}{*}{$R E_{x}=\frac{X_{w / 0}-X_{w}}{X_{w / 0}} \cdot 100$} & \multicolumn{3}{|c|}{ ETC 3 w/o slip catalyst } & \multicolumn{3}{|c|}{ ETC 4 Reference } & & & \\
\hline & \multicolumn{3}{|c|}{ with DPF + SCR } & \multicolumn{3}{|c|}{ without DPF + SCR } & \multicolumn{3}{|c|}{ RE [\%] } \\
\hline & $0-400 \mathrm{~s}$ & $\begin{array}{c}1400- \\
1800 \mathrm{~s}\end{array}$ & $0-1800 \mathrm{~s}$ & $0-400 \mathrm{~s}$ & \begin{tabular}{|c|}
$1400-1800$ \\
$\mathrm{~s}$
\end{tabular} & $0-1800 \mathrm{~s}$ & $0-400 \mathrm{~s}$ & $\begin{array}{c}1400- \\
1800 \mathrm{~s}\end{array}$ & $0-1800 s$ \\
\hline Temp. T $7\left[{ }^{\circ} \mathrm{C}\right]$ & 278 & 197 & 259 & 271 & 195 & 255 & & & \\
\hline $\mathrm{NO}_{\mathbf{x}}$ 1CLD [ppm] & 47 & 390.9 & 290.1 & 605.9 & 504.7 & 699.8 & 92 & 23 & 59 \\
\hline $\mathrm{NO}_{\mathbf{x}}$ FTIR [ppm] & 53 & 426.2 & 317 & 660.8 & 550.5 & 759.7 & 92 & 23 & 58 \\
\hline $\mathrm{NO}_{2}$ 1CLD [ppm] & 3 & 42.6 & 35.9 & 39 & 49.2 & 48.6 & 92 & 13 & 26 \\
\hline $\mathrm{NO}_{2}$ FTIR [ppm] & 2.4 & 48.5 & 38 & 29.2 & 53.21 & 40.4 & 92 & 9 & 6 \\
\hline$\left[1 / \mathrm{cm}^{3}\right]$ & $3.3 E+04$ & $7.6 \mathrm{E}+03$ & $2.1 \mathrm{E}+04$ & $4.5 E+06$ & $5.9 \mathrm{E}+06$ & $6.2 E+06$ & 99 & 100 & 100 \\
\hline PAS $\left[\mu \mathrm{gEC} / \mathrm{m}^{3}\right]$ & 65.9 & 65.4 & 60.9 & 6734.8 & 8638.5 & 8635.6 & 99 & 99 & 99 \\
\hline$\left[\mu \mathrm{m}^{2} / \mathrm{cm}^{3}\right]$ & 293.8 & 200.1 & 243.3 & 37460.6 & 41075.4 & 45724.5 & 99 & 100 & 99 \\
\hline
\end{tabular}

Table 5: Integral average values and reduction efficiencies of $\mathrm{NO}_{x}, \mathrm{NO}_{2}$ \& NP in different parts of the ETC, (LEM).

In the operating point OP1 of the stationary 4-points test, the influence of the secondary formation of nanoparticles is visible. In the dynamic test, such effects are hardly detectable, due to overlapping and blurring of all transient effects.

In the dynamic ETC test, the DPF which fullfills VERT quality standards, is as efficient as in stationary tests. Moreover, in stationary testing it is possible to observe phenomena, which are not visible in the transient tests. Such effects can be: storage/ release of sulfates in the exhaust system, influences of additive-particles, or secondary SCR nanoparticles. The stationary testing of DPFs according to the VERT procedures can be confirmed as the best solution.

Further tests were performed with different driving cycles with non limited engine map (NEM).

The conditioning of the engine and exhaust system was for ETC and WHTC identical, as for the previous tests with LEM (see Test Procedures): after warm-up 5 min $2200 \mathrm{rpm} / \mathrm{FL}$ and 0,5 min idling.

For the low-load cycles (NYCC and Braunschweig) the conditioning was: $5 \mathrm{~min} 1600 \mathrm{rpm} / 165 \mathrm{Nm}$ and 0,5 min idling.

Fig. 17 shows in the ETC much better $\mathrm{NO}_{x}$ conversion rates in the later phase of the cycle, than with the limited engined map (Fig. 15). This is due to the higher average exhaust gas temperature and more advantageous urea dosing.

Fig. 18 represents the time-plots of tailpipe temperature over the cycle duration for other investigated test cycles.

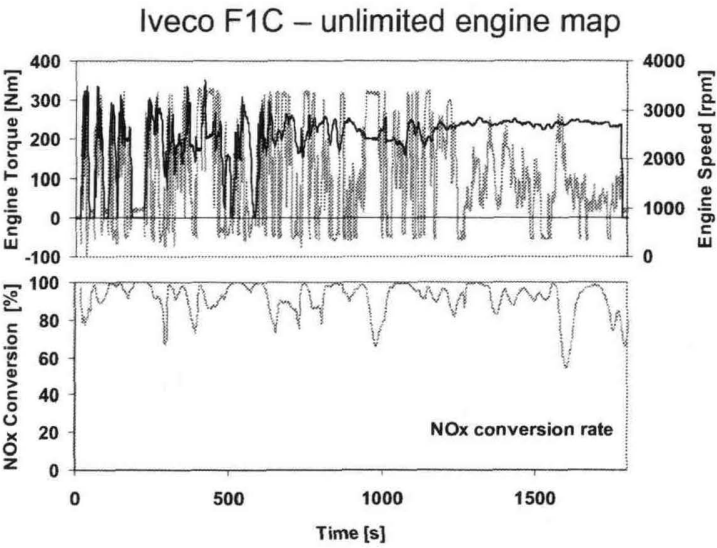

Fig. 17: $\mathrm{NO}_{\mathrm{x}}$ conversion rate in ETC with full operating range of the engine, $\alpha=0.9$, (NEM)

Iveco F1C - unlimited engine map

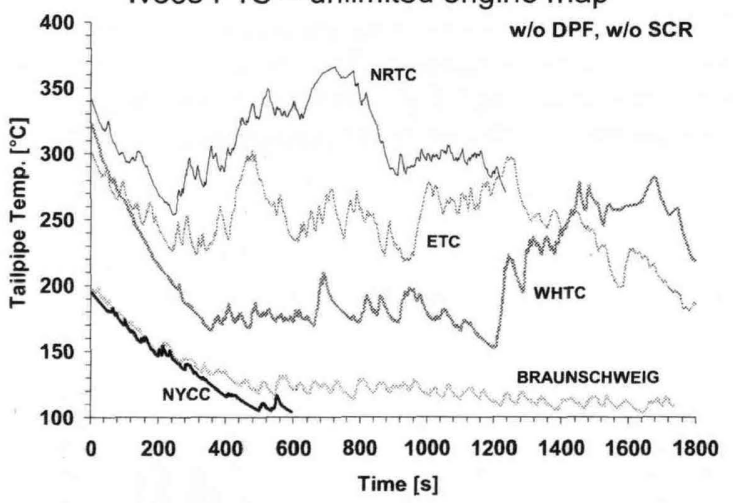

Fig. 18: Engine tailpipe temperature in different cycles (w/o exhaust gas aftertreatement, NEM). 
The New York City Cycle (NYCC) and the Braunschweig-Cycle are low-load cycles, which were developed in those cities and represent the city bus driving.

It can be seen, that the exhaust temperatures in the low load cycles are too low to enable the full working potential of the SCR-system.

Table 6 depicts the integral average emissions measured with different methods and the conversion rates in different driving cycles.

In the Braunschweig-Cycles there are the lowest $\mathrm{NO}_{x}$ conversion rates.

\begin{tabular}{|c|c|c|c|c|c|c|c|c|}
\hline & \multicolumn{2}{|c|}{ ETC } & \multicolumn{2}{|c|}{ WHTC } & \multicolumn{2}{|c|}{ NYCC } & \multicolumn{2}{|c|}{ Braunschweig } \\
\hline & \multicolumn{2}{|c|}{$1800 \mathrm{~s}$} & \multicolumn{2}{|c|}{$1800 \mathrm{~s}$} & \multicolumn{2}{|c|}{$598 \mathrm{~s}$} & \multicolumn{2}{|c|}{$1740 \mathrm{~s}$} \\
\hline & OEM & $\begin{array}{c}\text { DPF+ } \\
2 \times S C R\end{array}$ & OEM & $\begin{array}{c}\text { DPF+ } \\
2 \times S C R\end{array}$ & OEM & $\begin{array}{c}\text { DPF+ } \\
2 \times S C R\end{array}$ & OEM & $\begin{array}{c}\text { DPF+ } \\
2 \times S C R\end{array}$ \\
\hline$[$ [/test] & 4.15 & 4.3 & 2.58 & 2.64 & 0.246 & 0.26 & 1.02 & 1.05 \\
\hline $\mathrm{T}$ Engine Out $\left[{ }^{\circ} \mathrm{C}\right]$ & 281 & 310 & 247 & 261 & 144 & 150 & 149 & 156 \\
\hline T Tailpipe & 248 & 290 & 210 & 241 & 138 & 181 & 127 & 150 \\
\hline $\mathrm{NO}_{x} 2 \mathrm{CLD}$ & 278 & 26 & 275 & 97 & 115 & 67 & 127 & 107 \\
\hline $\mathrm{NO}_{\mathrm{x}} \mathrm{FTIR}$ & 314 & 31 & 303 & 108 & 123 & 74 & 124 & 107 \\
\hline $\mathrm{NO}_{2} 2 \mathrm{CLD}$ & 26 & 2 & 23 & 16 & 21 & 3 & 22 & 5 \\
\hline $\mathrm{NO}_{2} \mathrm{FTIR}$ & 26 & 2 & 29 & 19 & 25 & 1 & 26 & 2 \\
\hline $\mathrm{N}_{2} \mathrm{O}$ FTIR & 0.3 & 0.7 & 0.2 & 1.1 & 0.2 & 1.0 & 0.3 & 1.0 \\
\hline $\mathrm{NH}_{3}$ LDS & 0.0 & 5.0 & 0.0 & 1.0 & 0.0 & 0.0 & 0.0 & 0.0 \\
\hline $\mathrm{NH}_{3} \mathrm{FTIR}$ & 0.0 & 8.4 & 0.0 & 1.5 & 0.1 & 0.0 & 0.0 & 0.1 \\
\hline
\end{tabular}

\begin{tabular}{|c|c|c|c|c|}
\hline \multirow{2}{*}{$\mathrm{RE}_{\mathrm{x}}=\frac{\mathrm{X}_{\mathrm{w} / \mathrm{o}}-\mathrm{X}_{\mathrm{w}}}{\mathrm{X}_{\mathrm{w} / \mathrm{o}}} \cdot 100$} & \multicolumn{4}{|c|}{ RE [\%] } \\
\hline & ETC & WHTC & NYCC & BRAUN \\
\hline $\mathrm{NO}_{x} 2 \mathrm{2CLD}$ & 91 & 65 & 42 & 16 \\
\hline $\mathrm{NO}_{\mathrm{x}}$ FTIR & 90 & 64 & 40 & 14 \\
\hline $\mathrm{NO}_{2} 2 \mathrm{CLD}$ & 93 & 33 & 87 & 76 \\
\hline $\mathrm{NO}_{2}$ FTIR & 91 & 35 & 98 & 92 \\
\hline
\end{tabular}

Table 6: Integral average emissions and $\mathrm{NO}_{x}$ conversion rates in different driving cycles ETC, WHTC,NYCC \& Braunschweig-Cycle, $\alpha=0.9$, (NEM)

More information about the research at different driving cycles will be reported separately.

Finally it must be followed, that the investigated SCRsystem in the present configuration is a little efficient $\mathrm{NO}_{x}$ reduction measure in the low-load city driving.

\section{CONCLUSIONS}

The most important results from the investigated combined DPF+SCR system for transient applications can be summarized as follows:

- the combined dePN systems (DPF+SCR) at transient engine operation efficiently reduce the target emissions with deNO $\mathrm{N}_{\mathrm{x}}$-efficiencies up to $92 \%$ (if operated in the right temperature window) and particle number filtration efficiencies up to $100 \%$,

- with increasing feed factor (up to overstoichiometric urea dosing) $\mathrm{NO}_{x}$ conversion efficiencies increase (up to $98 \%$ ), but also the ammonia slip rises up to $125 \mathrm{ppm}$,

- $\quad$ with the recommended feed factor $\alpha=0.9$, without slip catalyst, and there is only a moderate average slip of ammonia up to $7 \mathrm{ppm}$ in the ETC and there is a release of small amounts of nitrous oxide of up to $3 \mathrm{ppm}$,

- the ammonia slip can be efficiently eliminated by a slip-cat,

- during transients there are temporarily increased emissions of nitrogen-containing components, due to momentary imbalanced deNOx reactions,

- in the investigated configuration with urea dosing after the DPF, a secondary formation of nanoparticles is detectable, however with little impact on total number concentrations and overall filtration efficiency of the system,

- the average $\mathrm{NO}_{\mathrm{x}}$ conversion efficiency at transient operation (ETC) strongly depends on the exhaust temperatures which are correlated with the ureadosing strategy; during low-load operation this efficiency is strongly reduced,

- the nanoparticle filtration efficiency, which is verified at stationary engine operation, is perfectly valid also at transient engine operation.

The presented exemplary results concern the part of testing procedures on engine dynamometer. They will be confirmed in the further project activities with other systems and with different testing cycles. A special attention will be paid to the operational profiles, which are representative for low emissions zones LEZ.

The entire VERTdePN testing procedure is still under development. 


\section{ACKNOWLEDGEMENT}

The authors want to express their gratitude for the financial support and realisation of the project to the:

- Swiss Federal Office of Environment BAFU, Mr. D. Zürcher

- Swiss Federal Office for Roads ASTRA, Mr. K. Meyer, Mr. Th. Gasser

- Swiss Occupational Insurance SUVA, Mr. B. Tobler, Mr. S. Siegrist

Further thanks are expressed to:

- IVECO Switzerland for the research engine and help with engine setting

Mr. M. Signer, Mr. E. Mathis, Mr. R. Zellweger

\section{LITERATURE}

[1] whw lowemissionzones.e.

[2] Frank, W.; Hüthwohl, G. Maurer, B.: SCRTechnologie für Nutzfahrzeuge. Purem Abgassysteme GmbH, MTZ 9/2004, S. 632

[3] Jacob, E.: Ammonia Generators for GD-KAT (advanced SCR) Systems. MAN. 2. Emission Control 2004, TU Dresden 17/18 Juni 2004

S. 358

[4] Lambert, Ch.; Hammerle, R.; Mc Gill, R.; Khair, M.; Sharp, Ch.: Technical Advantages of Urea SCR for Light-Duty and Heavy-Duty Diesel Vehicle Applications. Ford Research, Oak Ridge National Laboratory, Southwest Research Institute, SAE Paper 2004-01-1292.

[5] Hug, H.T., Mayer,A., Hartenstein, A. : OffHighway Exhaust Gas After-Treatment Combining UREA-SCR, Oxidation Catalysis and Traps; SAE 930363

[6] Hinz, A.; Jarvis, T.; et.al. "Field Test Trucks Fulfilling EPA '07 Emission Levels On-Road by Utilizing the Combined DPF and Urea-SCR System. Volvo, Johnson Mattey, Chevron, Bosch, SAE Techn. Paper 2006-01-0421

[7] Arrowsmith, D.; Bott, A.; Busch, Ph.: "Development of a Compact Urea-SCR + CRT System for Heavy-Duty Diesel Using a Design of Experiments Approach. Eminox Ltd., SAE Techn. Paper 2006-01-0636

[8] Rusch, K.; Kaiser, R.; Hackenberg, S.: DPF SCR Combinations Integrated Systems to Meet Future LDV Emission Limits. Arvin Meritor, SAE Techn. Paper 2006-01-0637
[9] Hümekes, E.; Neubauer, T.; Roth, S.; Patchett, J.: Selective Catalytic Reduction (SCR) for Mobile Application - Heavy Duty Diesel. Engelhard.

$4^{\text {th }}$ International Exhaust Gas and Particulate Emissions Forum, AVL, Ludwigsburg March 2006, p. 109.

[10] Martin, S.; Gehrlein, J.; Kotrba, A.; Lacin, F.: Urea SCR System Characterization through Unique Flow Bench Testing, SAE Techn. Paper 2006-01-3471

[11] Jacob, E.; Müller, R.; Scheeder, A.; Cartus, T.; Dreisbach, R.; Mai, H.-P.; Paulus, M.; Spengler, J.: High Performance SCR Catalyst System: Elements to Guarantee the Lowest Emissions of $\mathrm{NO}_{x}$.27. Internationales Wiener Motorensymposium 2006. Bd.2.

[12] Cartus, T.; Schüssler, $M$.; Herrmuth, $H_{\text {.; }}$; Giovanella, M.: SCR and DPF - From Concept to Production. Mastering Complex, MutliDimensional Challenges.

28. Internationales Wiener Motorensymposium 2007. Bd.1.

[13] Willems, F.; Cloudt, R.; van den Eijnden, E.; Van Genderen, M.; Verbeek, R.; de Jager, B.; Boomsma, W.; van den Heuvel, I.: Is ClosedLoop SCR Control Required to Meet Future Emission Targets? SAE Techn. Paper 2007-011574

[14] Pischinger, S.; Körfer, T.; Wiartalla, A.; Schnitzler, J.; Tomazic, D.; Tatur, M.: Combined Particulate Matter and $\mathrm{NO}_{x}$ Aftertreatment Systems for Stringent Emission Standards. SAE Techn. Paper 2007-01-1128

[15] Hosoya, M.; Kawada, Y.; Sato, S.; Shimoda, M.: The Study of $\mathrm{NO}_{x}$ and PM Reduction Using Urea Selective Catalytic Reduction System for Heavy Duty Diesel Engine. SAE Techn. Paper 200701-1576

[16] Görsmann, C.: Retrofit SCRT ${ }^{\circledR}-$ A retrofit system for the simultaneous reduction of carbon monoxide, hydrocarbon, soot particulate and oxides of nitrogen emissions from commercial vehicles, 4. FAD - Konferenz, Dresden, Nov. 2006, p. 155.

[17] Girard, J-W.; Cavataio, G.; Lamber, Ch. K.: The Influence of Ammonia Slip Catalysts on Ammonia, $\mathrm{N}_{2} \mathrm{O}$ and $\mathrm{NO}_{x}$ Emissions for Diesel Engines. SAE Techn. Paper 2007-01-1572

[18] Xu, L.; Watkins, W.; Snow, R.; Graham, G.; McCabe, R.; Lambert, Ch.; Carter III, R.O.: Laboratory and Engine Study of Urea-Related Deposits in Diesel Urea-SCR After-Treatment Systems. SAE Techn. Paper 2007-01-1582 
[19] Girard, J.; Snow, R.; Cavataio, G.; Lambert, Ch.: The Influence of Ammonia to $\mathrm{NO}_{x}$ Ratio on SCR Performance. SAE Techn. Paper 2007-01-1581

[20] Hoard, J.; Snow, R.; Xu, L.; Gierczak, Ch.; Hammerle, R.; Montreuil, C.; Farooq, S.I.: $\mathrm{NO}_{x}$ Measurement Errors in Ammonia-Containing Exhaust. SAE Techn. Paper 2007-01-0330

[21] Shah, S.D.; Mauti, A.; Richert, J.F.O.; Loos, M.J.; Chase, R.E.: Measuring $\mathrm{NO}_{x}$ in the Presence of Ammonia. SAE Techn. Paper 2007-01-0331

[22] Shah, S.D.; Mauti, A.; Richert, J.F.O.; Chase, R.E.:The Oxidation of $\mathrm{NO}$ to Yield $\mathrm{NO}_{2}$ in Emissions Testing Sample Bags. SAE Techn. Paper 2007-01-0332

[23] Particulate traps for heavy duty vehicles. Environmental Documentation No. 130, Swiss Agency for Environment, Forests and Landscape (SAEFL, since Jan. 06 BAFU), Bern 2000

[24] VERT, Final Report, 29.2.2000, Available from SUVA (Swiss National Accident Insurance Organization) Lucerne, Wmw suva ch.

[25] VERT Filter List, tested and approved particle trap systems for retrofitting Diesel engines, whw umwels schweiz ch

[26] Mayer, A.; Czerwinski, J.: VERT Particulate Trap Verification. IX. International Conference "R \& D of Internal Combustion Engines", Vladimir, Russia, May 27-29,2003 (ISBN 5-86953-048-2) p. 92 (SAE 2002-01-0435).

[27] Mayer, A.; Czerwinski, J.; Pétermann, J.-L.; Wyser, M.; Legerer, F.: "Reliability of DPFSystems: Experience with 6000 Applications of the Swiss Retrofit Fleet. SAE Paper 2004-010076, TTM, AFHB, BUWAL, AKPF.

[28] Minimierung der Partikelemissionen von Verbrennungsmotoren. Teil 1: Grundlagen, Wirkungen, Messtechnik und Grenzwerte. München 15. Mai 2006, Veranstaltung $\mathrm{Nr}$. E-H030-05-185-6, Haus der Technik, Essen, mum holmessende.

[29] Sessions: Measurement Technics \& Health Effects, $9^{\text {th }}$ ETH \& $10^{\text {th }}$ ETH Conference on Combustion Generated Particles, Zürich Aug. 15-17. 2005 \& Zürich Aug. 21-23. 2006 , mwm nanoparticles ethz ch

[30] Mayer, A. \& 81 coautors: Elimination of Engine Generated Nanoparticles, Problems and Solutions. Haus der Technik Handbuch, Band 58, Expert Verlag 2005, wmw experiverlag de

[31] Informationen über GRPE PMP-Programm:

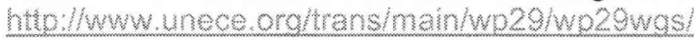
wo29aroelarpeage.hrm!
[32] Mohr, M.; Lehmann, U.: Comparison Study of Particle Measurement Systems for Future Type Approval Application. EMPA Report: 202779, May 2003. Swiss contribution to GRPE Particle Measurement Programme (GRPE-PMP CH5)

[33] Andersson, J.; Clarke, D.: UN-GRPE PMP Phase 3 Inter-laboratory Correlation Exercise: Frame-work and Laboratory Guide. A Document for the UK Department of Transport. Ricardo Consulting Engineers. Report No. RD 04/80 801.5; Q55022, Feb. 2005

\section{ABBREVIATIONS}

$\begin{array}{ll}\text { AEEDA } & \begin{array}{l}\text { Association Européenne } \\ \text { d'Experts en Dépollution des }\end{array} \\ \text { AFHB } & \text { Automobiles, Belgium } \\ \text { AKPF } & \text { Abgasprüfstelle FH Biel, CH } \\ & \begin{array}{l}\text { Arbeitskreis der } \\ \text { Partikelfilterhersteller, Austria }\end{array} \\ \text { ASTM } & \text { stoichiometric air requirement } \\ \text { Materials } & \text { American Society for Testing } \\ \text { ASTRA } & \text { Amt für Strassen, CH, Swiss Road } \\ & \text { Authority } \\ \text { AUVA } & \text { Austria Unfall Versicherung-Anstalt } \\ \text { BAFU } & \text { Bundesamt für Umwelt, CH (Swiss } \\ \text { EPA) } & \text { Californian Air Resources Board } \\ \text { CARB } & \text { Common Rail Diesel Injection } \\ \text { CDI } & \text { cold filter plugging point } \\ \text { CFPP } & \text { chemoluminescence } \\ \text { CLD } & \text { condensation nuclei counter } \\ \text { CNC } & \text { conformity of production } \\ \text { COP } & \text { condensation particle counter } \\ \text { CPC } & \text { Diffusion Charging Sensor } \\ \text { DC } & \text { de Particles + deNOx } \\ \text { dePN } & \text { Direct Injection } \\ \text { DI } & \text { differential mobility analyzer } \\ \text { DMA } & \text { Diesel Particle Filter } \\ \text { DPF } & \text { electronic control unit } \\ \text { ECU } & \text { electric low pressure impactor } \\ \text { ELPI } & \text { Eidgenössische Material Prüf- und } \\ \text { EMPA } & \text { Forschungsanstalt } \\ \text { EPA } & \text { Environmental Protection Agency } \\ \text { ETC } & \text { European Transient Cycle } \\ \text { FAD } & \text { Förderkreis Abgasnachbehandlungs- } \\ & \text { technologien für Dieselmotoren, } \\ \text { FBC } & \text { Germany } \\ \text { FE } & \text { fuel borne catalyst (regeneration } \\ \text { FID } & \text { additive) } \\ \text { FOEN } & \text { filtration efficiency } \\ & \text { flame ionization detector } \\ \text { FL lodice of Environment (BAFU) }\end{array}$




$\begin{array}{ll}\text { FTIR } & \text { Fourrier Transform Infrared } \\ \text { GRPE } & \text { Spectrometer } \\ & \text { UN Groupe of Rapporteurs Pollution \& } \\ \text { HD } & \text { Energie } \\ \text { ICE } & \text { heavy duty } \\ \text { IUCT } & \text { internal combustion engines } \\ \text { JRC } & \text { in use compliance test } \\ \text { LDS } & \text { EU Joint Research Center } \\ \text { LEM } & \text { Laser Diode Spectrometer (for } \mathrm{NH}_{3} \text { ) } \\ \text { LEZ } & \text { limited engine map } \\ \text { LRV } & \text { low emission zones } \\ \text { ME } & \text { Luftreinhalteverordnung } \\ \text { MD19 } & \text { Matter Engineering } \\ \text { NanoMet } & \text { heated minidiluter } \\ & \text { NanoMetnanoparticle summary } \\ \text { NEM } & \text { surface analyser (PAS + DC + MD19) } \\ \text { NP } & \text { PAS + DC + sampling \& dilution unit } \\ \text { NRTC } & \text { nonlimited engine map } \\ \text { NYCC } & \text { nanoparticles }<\text { 999 nm (SMPS range) } \\ \text { OEM } & \text { nonroad transient cycle } \\ \text { OP } & \text { New York City Cycle } \\ \text { PAS } & \text { opinal equipment manufacturer } \\ \text { PC } & \text { Photoelectric Aerosol Sensor } \\ \text { PCFE } & \text { particle counts } \\ \text { PM } & \text { particle counts filtration efficiency } \\ \text { PMFE } & \text { particulate matter, particle mass } \\ \text { PMP } & \text { particle mass filtration efficiency } \\ & \text { Particulate Measurement } \\ \text { PSD } & \text { Program of GRPE } \\ \text { PSI } & \text { particle size distribution } \\ \text { RD } & \text { Paul Scherrer Institute } \\ \text { RE } & \text { relative difference } \\ & \text { reduction efficiency } \\ & \end{array}$

$\begin{array}{ll}\text { SCR } & \text { selective catalytic reduction } \\ \text { SMPS } & \text { Scanning Mobility Particle Sizer } \\ \text { SNORB } & \text { Swiss NO Retrofit Benchmark } \\ \text { SP } & \text { sampling position } \\ \text { SUVA } & \text { Schweiz. Unfallversicherungs- } \\ & \text { Anstalt } \\ \text { TBG } & \text { Tiefbaugenossenschaft } \\ \text { TC } & \text { thermoconditioner. Total Carbon } \\ \text { TNO } & \text { Netherland National, Laboratories } \\ \text { TÜV } & \text { Technischer Überwachungsverein, D } \\ \text { ULSD } & \text { ultra low sulfur Diesel } \\ \text { UMTEC } & \text { Umwelttechnik Institut FH } \\ & \text { Rapperswil, CH } \\ \text { US-EPA } & \text { US - Environmental Protection } \\ & \text { Agency } \\ \text { VERT } & \text { Verminderung der Emissionen von } \\ & \text { Realmaschinen in Tunelbau } \\ \text { VERTdePN } & \text { VERT DPF + VERT deNO } \\ \text { VPNT1 } & \text { VERTdePN Test 1 - engine dyno } \\ \text { VPNT2 } & \text { VERTdePN Test 2 - field durability } \\ & \text { 2000h } \\ \text { VPNT3 } & \text { VERTdePN Test 3 - check after field } \\ & \text { test chassis dyno } \\ \text { VPNTSET } & \text { VERTdePN secondary emissions test - } \\ & \text { engine dyno } \\ \text { VROM } & \text { Netherlands EPA } \\ \text { VSET } & \text { VERT Secondary Emissions Test } \\ \text { WHTC } & \text { worldwide heavy duty transient cycle } \\ \alpha & \text { feed factor of urea dosing; } \\ & \text { ratio: urea injected / urea stoichio- } \\ & \text { metric; calculated by the ECU. } \\ & \end{array}$

